\title{
Clotrimazole Scaffold as an Innovative Pharmacophore Towards Potent Antimalarial Agents: Design, Synthesis, and Biological and Structure-Activity Relationship Studies
}

\author{
Sandra Gemma, ${ }^{\dagger,}$ Giuseppe Campiani, ${ }^{*}, \dagger$ Stefania Butini, ${ }^{\dagger,}$ Gagan Kukreja, ${ }^{\dagger \dagger}$ Salvatore Sanna Coccone, ${ }^{\dagger, \ddagger}$ \\ Bhupendra P. Joshi, ${ }^{\dagger, \ddagger}$ Marco Persico, ${ }^{\dagger, \S}$ Vito Nacci, ${ }^{\dagger, \ddagger}$ Isabella Fiorini, ${ }^{\dagger, \ddagger}$ Ettore Novellino, ${ }^{\dagger, \| l}$ Ernesto Fattorusso, ${ }^{\dagger, \S}$ \\ Orazio Taglialatela-Scafati, ${ }^{\dagger, \S}$ Luisa Savini, ${ }^{\dagger, \ddagger}$ Donatella Taramelli, ${ }^{\dagger,},{ }^{\prime}$ Nicoletta Basilico,,${ }^{\dagger, \#}$ Silvia Parapini, ${ }^{\dagger, \perp}$ Giulia Morace, ${ }^{\perp}$ \\ Vanessa Yardley, ${ }^{\dagger, \nabla}$ Simon Croft, ${ }^{\dagger, \nabla}$ Massimiliano Coletta, ${ }^{\perp}$ Stefano Marini, ${ }^{\#}$ and Caterina Fattorusso ${ }^{\dagger, \S}$ \\ European Research Centre for Drug Discovery and Development and Dipartimento Farmaco Chimico Tecnologico, Università di Siena, via \\ Aldo Moro, 53100 Siena, Italy, Dipartimento di Chimica delle Sostanze Naturali and Dipartimento di Chimica Farmaceutica e Tossicologica, \\ Università di Napoli Federico II, via D. Montesano 49, 80131 Napoli, Italy, Dipartimento di Sanità Pubblica-Microbiologia-Virologia, \\ Universita' di Milano, Via Pascal 36, 20133 Milano, Italy, Department of Infectious, Tropical Diseases, London School of Hygiene and \\ Tropical Medicine, Keppel Street, London WC1E 7HT, United Kingdom, and Dipartimento di Medicina Sperimentale e Scienze Biochimiche, \\ Università degli Studi di Roma Tor Vergata, Rome, Italy
}

Received October 2, 2007

\begin{abstract}
We describe herein the design, synthesis, biological evaluation, and structure-activity relationship (SAR) studies of an innovative class of antimalarial agents based on a polyaromatic pharmacophore structurally related to clotrimazole and easy to synthesize by low-cost synthetic procedures. SAR studies delineated a number of structural features able to modulate the in vitro and in vivo antimalarial activity. A selected set of antimalarials was further biologically investigated and displayed low in vitro toxicity on a panel of human and murine cell lines. In vitro, the novel compounds proved to be selective for free heme, as demonstrated in the $\beta$-hematin inhibitory activity assay, and did not show inhibitory activity against $14-\alpha$-lanosterol demethylase (a fungal P450 cytochrome). Compounds $\mathbf{2}$, 4e, and $\mathbf{4 n}$ exhibited in vivo activity against $P$. chabaudi after oral administration and thus represent promising antimalarial agents for further preclinical development.
\end{abstract}

\section{Introduction}

Despite the considerable efforts of academic and industrial research, malaria exacts a devastating social and economic cost across the globe. The disease causes 2-3 million deaths per annum as well as incalculable suffering. It strikes hardest at some of the poorest nations and is itself a significant cause and consequence of poverty. Its effects are not only limited to the developing nations, but malaria is of serious concern to travelers, especially in the absence of a vaccine and in the face of widespread resistance to several antimalarial drugs. ${ }^{1}$

The etiological agent of malaria is Plasmodium falciparum $(P f)$, a highly evolved unicellular parasite whose life cycle, shared between an Anopheline mosquito vector and the human host, exhibits striking biological features that have been exploited to seek intervention strategies for malaria therapy. The detoxification of free heme released in the food vacuole (FV) of $P f$ during host hemoglobin $(\mathrm{Hb})$ catabolism represents a unique biochemical process. It imposes a significant oxidative burden $^{2}$ that has to be managed by the plasmodium through specific mechanisms of heme detoxification such as crystallization of heme to hemozoin and degradation in the presence of reduced glutathione. ${ }^{3}$ Interference with such processes through

* To whom correspondence should be addressed. Phone: 0039-0577234172. Fax: 0039-0577-234333. E-mail: campiani@unisi.it.

${ }^{\dagger}$ European Research Centre for Drug Discovery, Università di Siena.

‡ Dipartimento Farmaco Chimico Tecnologico, Università di Siena.

$\S$ Dipartimento di Chimica delle Sostanze Naturali, Università di Napoli.

"Dipartimento di Chimica Farmaceutica e Tossicologica, Università di Napoli.

${ }^{\nabla}$ London School of Hygiene and Tropical Medicine.

${ }^{\perp}$ Dipartimento di Sanità Pubblica-Microbiologia-Virologia, Universita' di Milano.

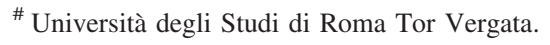

interaction with free heme and exacerbation of oxidative stress are supposed to be the mode of action of two of the most popular and effective classes of antimalarial agents, namely, 4-aminoquinolines and endoperoxides. Before the appearance of resistance, chloroquine (CQ) was one of the most successful antimicrobial agents ever developed, while artemisinins represent at the moment the most effective therapeutic option for the treatment of resistant malaria, although there is concern of overgrowing evidence for the in vitro appearance of artemisininresistant plasmodia. ${ }^{4}$ The high efficacy of these antimalarials resides in their ability to specifically target free heme (in its $\mathrm{Fe}(\mathrm{III})$ or $\mathrm{Fe}(\mathrm{II})$ forms, respectively) and to interfere with the fragile redox balance necessary for plasmodium survival. Moreover, their low propensity to induce resistance (resistance to CQ only occurred after many years of heavy drug pressure) is due to the lack of interaction with a specific protein target. Consequently, specific interaction with free heme aimed at inhibiting heme detoxification and increasing oxidative stress still represents a valuable strategy for the discovery of potential antimalarial drugs selectively toxic for the plasmodium.

Within a program aimed at developing new antimalarial drugs, ${ }^{5}$ we recently reported the identification of a new polyaromatic antimalarial pharmacophore based on clotrimazole (CLT, 1, Chart 1) scaffold. ${ }^{6}$

CLT is a well-known antimycotic drug which exhibits a weak in vitro antimalarial activity against different $P f$ strains and importantly, irrespective of their CQ sensitivity. ${ }^{7,8}$ Biological activities of CLT are mediated by its ability to interact with ferri-protoporphyrin IX (Fe(III)-FP), which is present as the prosthetic group in several enzymes, such as (i) $14 \alpha$-lanosteroldemethylase (14-LD), the fungal cytochrome inhibited by CLT, (ii) human P450 cytochromes, which are inhibited by CLT causing altered metabolism of both xenobiotics and endogenous 
Chart 1. Reference and Title Compounds

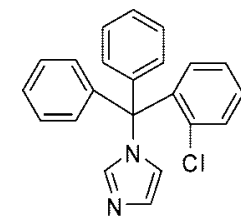

1, CLT

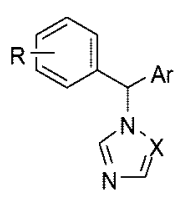

$( \pm)-3 a-h$

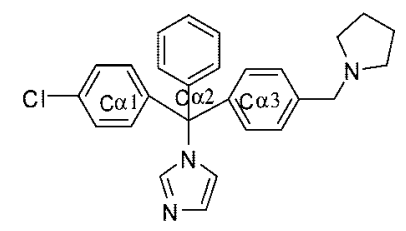

$( \pm)-2$
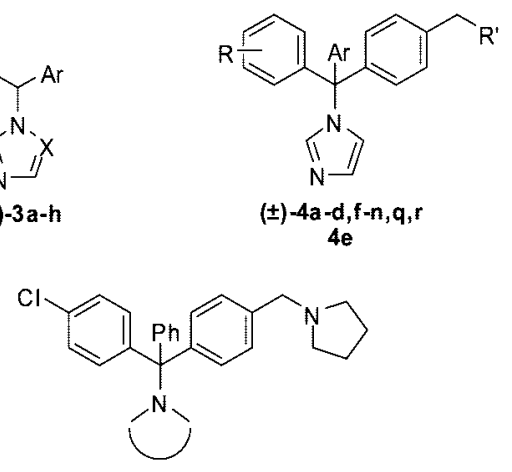

( \pm$)-40$, benzimidazole

( \pm ) $-4 p$, piperazine chemicals, and (iii) hemoperoxidase, ${ }^{9}$ a $P f$-derived enzyme, which is inhibited by CLT, in the presence of $\mathrm{H}_{2} \mathrm{O}_{2}$, by a mechanism based on CLT-one electron oxidation product. Moreover, CLT is also able to form in vitro complexes with free $\mathrm{Fe}(\mathrm{III})-\mathrm{FP}$ in which the imidazole ring behaves as a Fe(III) axial ligand and is able to inhibit in vitro the crystallization of free $\mathrm{Fe}(\mathrm{III})$-FP into $\beta$-hematin. ${ }^{10,11}$

Based on the aforementioned properties of CLT and considering its peculiar chemical structure, characterized by (i) an imidazole ring, known to mediate electron transfer reactions in biological systems, ${ }^{12,13}$ and (ii) a triphenylmethyl system, known to form and stabilize a radical intermediate (the triphenylmethyl radical was a landmark discovery as it marked the beginning of organic free radical chemistry ${ }^{14}$ ), we hypothesized that CLT, in the unique FV chemical environment, could interact with hemoglobin-derived ferro-protoporphyrin IX (Fe(II)-FP) and to get activated to form toxic trityl radicals able to kill the parasite by oxidative damage.

Consequently, our design strategy mainly focused on the synthesis of analogues with specific electronic and chemical features to better penetrate and accumulate into the FV and to generate active radical intermediates therein $(\mathrm{pH} 5.5$ and presence of heme). Furthermore, we envisioned to improve the selectivity for free heme over heme as a prosthetic group to minimize side effects. These studies led to the identification of the CLT analogue $2{ }^{6}$ a novel hit endowed with potent antimalarial activity in vitro whose structure is characterized by the presence of a protonatable pyrrolidinylmethyl group, which was rationally introduced to improve the pharmacokinetic properties, to increase tropism for the acidic FV and to attain selectivity for free heme over heme into cytochromes (due to the presence of conserved protonated amino acid residues at the lip of the cytochrome active site).

Here we report the synthesis and the biological evaluation of two series of compounds $(\mathbf{3 a}-\mathbf{h}$ and $\mathbf{4 a}-\mathbf{r})$ based on the innovative polyaromatic pharmacophore previously disclosed. ${ }^{6}$ Structure-activity relationships for the novel series of antimalarials were investigated through structural modifications performed at the protonatable lateral chain of $\mathbf{2}$, at the polyaromatic scaffold, introducing various heterocycles and substituted phenyl rings, and at the heme complexing moiety. Among the compounds synthesized, the most active were selected for further biological investigation to establish (i) the antiplasmodial activity in vivo against murine plasmodia such as $P$. berghei and $P$. chabaudi, (ii) the antifungal activity predictive for their capability to interact with P450 cytochromes (protein-bound heme), and (iii) their ability to interact with $\mathrm{Fe}$ (III)-FP in vitro. Compounds $\mathbf{4 e}$ and $\mathbf{4 n}$ were identified as promising antimalarial agents suitable for further development.

\section{Chemistry}

Compounds $\mathbf{3} \mathbf{a}-\mathbf{g}$ reported in Table 1 were synthesized according to Schemes 1 and 2. Intermediate 7a (Scheme 1) was synthesized starting from $\mathbf{6},{ }^{15}$ transformed into the corresponding Grignard reagent, and coupled with $\mathbf{5}$, while $\mathbf{7 b}$ was obtained starting from the bromo derivative $\mathbf{8},{ }^{6}$ after its transformation into the Boc-piperazine intermediate 9. Subsequently, carbinols 7a,b were transformed into the corresponding chlorides by exposure to thionyl chloride, followed by reaction with imidazole or $1 H$-1,2,4-triazole, in the presence of triethylamine, to afford the final compounds $\mathbf{3 a}-\mathbf{c}$. Finally, treatment of $N$-Boc derivative $\mathbf{3 c}$ with trifluoroacetic acid in dichloromethane (DCM) gave the free piperazine-derivative $\mathbf{3 d}$.

Compounds $\mathbf{3 e}-\mathbf{g}$ were synthesized as depicted in Scheme 2. Commercially available aldehyde 11a was reacted with 3-chlorophenylmagnesium bromide to afford alcohol 13, while carbinols $\mathbf{1 4 a}, \mathbf{b}$ were synthesized coupling the Grignard reagent obtained from 12 with the appropriate aldehydes 11a,b. Aldehyde 11b was in turn prepared starting from the 4,7-dichloroquinoline $\mathbf{1 0}$ by a two-step procedure involving the introduction of a methyl group at the 4-position ${ }^{16}$ of the quinoline system, followed by selenium dioxide oxidation. Conversion of carbinols 13 and 14a,b into the corresponding chlorides, followed by treatment with the sodium salt of imidazole in $\mathrm{N}, \mathrm{N}$-dimethylformamide (DMF) afforded the final compounds $\mathbf{3 e}-\mathbf{g}$.

Compounds $\mathbf{4 a}-\mathbf{e}, \mathbf{o}, \mathbf{p}$ were obtained as described in Scheme 3. The alkylation of bromobenzyl intermediate $\mathbf{1 5}$ with diethylamine, morpholine, or $N$-Boc-piperazine furnished the corresponding ketones $\mathbf{1 6 a}-\mathbf{c}$. The latter were in turn reacted with phenylmagnesium bromide to afford carbinols $17 \mathbf{a}-\mathbf{c}$. On the other hand, carbinols $\mathbf{1 8 a}-\mathbf{c}$ were prepared starting from $\mathbf{1 6 d},{ }^{6}$ by reaction with $p$-fluorophenylmagnesium bromide (18a) or with the Grignard reagent derived from 12 (18b) or with phenylmagnesium bromide (18c). Following a described procedure, ${ }^{17}$ triarylcarbinols $\mathbf{1 7 a}-\mathbf{c}$ and $\mathbf{1 8 a}, \mathbf{b}$ were converted into the corresponding unstable chlorides which on reaction with imidazole in the presence of triethylamine afforded the target compounds $\mathbf{4 a}-\mathbf{e}$. The chloride derivative of $\mathbf{1 8} \mathbf{c}^{6}$ was used as a substrate for the synthesis of $\mathbf{4 o , p}$ by reaction with benzimidazole or piperazine, respectively.

The heterocyclic analogues $\mathbf{4 f}-\mathbf{l}$ were prepared according to Scheme 4. 3-Chlorophenylmagnesium bromide was reacted with two equivalents of the corresponding commercially available carboxaldehydes $19 \mathbf{a}-\mathbf{e}$ to afford ketones $\mathbf{2 0 a}-\mathbf{e}$, while the corresponding $p$-chloro-substituted derivatives $\mathbf{2 1 a}, \mathbf{b}$ were obtained starting from 4-chlorophenylmagnesium bromide and aldehydes 19a,b. The ketones thus obtained were subjected to a second Grignard reaction to afford carbinols $22 \mathbf{a}-\mathbf{e}$ and $23 \mathbf{a}, \mathbf{b}$, which were in turn transformed to final compounds $\mathbf{4 f - 1}$, as described above.

For the synthesis of the quinoline-derivatives $\mathbf{4 m , n}$ (Scheme 5), the intermediate ketones $\mathbf{2 6 a}, \mathbf{b}$ were prepared starting from 7-chloro-4-methoxyquinoline 24. ${ }^{18}$ Accordingly, compound 24 was reacted with phenylacetonitrile or 4-fluorophenylacetonitrile, in the 


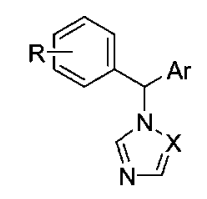

(士)-3a-h

\begin{tabular}{|c|c|c|c|c|c|c|c|c|c|c|}
\hline \multirow{2}{*}{ Compd } & \multirow{2}{*}{$\mathbf{R}$} & \multirow{2}{*}{$\mathbf{A r}$} & \multirow{2}{*}{$\mathbf{X}$} & \multicolumn{3}{|c|}{ Ionic form $(\%)^{a}$} & \multicolumn{4}{|c|}{$\mathbf{I C}_{\mathbf{5 0}}(\mathbf{n M})^{b}$} \\
\hline & & & & pH 7.4 & pH 7.2 & pH 5.5 & D10 ${ }^{c}$ & $\mathbf{W} 2^{d}$ & $3 \mathbf{D} 7^{c}$ & $\mathbf{K} \mathbf{1}^{d}$ \\
\hline $\mathbf{3 a}$ & $m-\mathrm{Cl}$ & & $\mathrm{CH}$ & $\begin{array}{l}\mathrm{DP}(10) \\
\mathrm{P}(89) \\
\mathrm{N}(1)\end{array}$ & $\begin{array}{l}\mathrm{DP}(15) \\
\mathrm{P}(85) \\
\mathrm{N}(0)\end{array}$ & $\begin{array}{l}\mathrm{DP}(90) \\
\mathrm{P}(10) \\
\mathrm{N}(0)\end{array}$ & 1888 & 1293 & 452 & 282 \\
\hline $\mathbf{3 b}$ & $m-\mathrm{Cl}$ & & $\mathrm{N}$ & $\begin{array}{l}\mathrm{P}(99) \\
\mathrm{N}(1)\end{array}$ & $\begin{array}{l}P(100) \\
N(0)\end{array}$ & $\begin{array}{l}P(100) \\
N(0)\end{array}$ & n.a. & n.a. & n.a. & 3701 \\
\hline $3 c$ & $m-\mathrm{Cl}$ & & $\mathrm{CH}$ & $\begin{array}{l}\mathrm{DP}(0) \\
\mathrm{P}(11) \\
\mathrm{N}(89)\end{array}$ & $\begin{array}{l}\mathrm{DP}(0) \\
\mathrm{P}(16) \\
\mathrm{N}(83)\end{array}$ & $\begin{array}{l}\mathrm{DP}(37) \\
\mathrm{P}(57) \\
\mathrm{N}(6)\end{array}$ & 5259 & 4109 & 1521 & 1071 \\
\hline $3 d$ & $m-\mathrm{Cl}$ & & $\mathrm{CH}$ & $\begin{array}{l}\mathrm{DP}(10) \\
\mathrm{P}(88) \\
\mathrm{N}(2)\end{array}$ & $\begin{array}{l}\mathrm{DP}(15) \\
\mathrm{P}(84) \\
\mathrm{N}(1)\end{array}$ & $\begin{array}{l}\mathrm{DP}(90) \\
\mathrm{P}(10) \\
\mathrm{N}(0)\end{array}$ & 516 & 411 & 327 & 354 \\
\hline $3 e$ & $m-\mathrm{Cl}$ & & $\mathrm{CH}$ & $\begin{array}{l}\mathrm{DP}(0) \\
\mathrm{P}(3) \\
\mathrm{N}(97)\end{array}$ & $\begin{array}{l}\mathrm{DP}(0) \\
\mathrm{P}(4) \\
\mathrm{N}(96)\end{array}$ & $\begin{array}{l}D P(5) \\
P(65) \\
N(30)\end{array}$ & n.a. & n.a. & n.a. & 4287 \\
\hline $3 f$ & & & $\mathrm{CH}$ & $\begin{array}{l}\mathrm{TP}(0) \\
\mathrm{DP}(3) \\
\mathrm{P}(96) \\
\mathrm{N}(1)\end{array}$ & $\begin{array}{l}\mathrm{TP}(0) \\
\mathrm{DP}(5) \\
\mathrm{P}(95) \\
\mathrm{N}(0)\end{array}$ & $\begin{array}{l}\text { TP(5) } \\
\text { DP(68) } \\
\text { P(27) } \\
\text { N(0) }\end{array}$ & 7483 & 5034 & 1790 & 379 \\
\hline $3 g$ & & & $\mathrm{CH}$ & $\begin{array}{l}\mathrm{DP}(2) \\
\mathrm{P}(97) \\
N(1)\end{array}$ & $\begin{array}{l}\mathrm{DP}(4) \\
\mathrm{P}(96) \\
\mathrm{N}(0)\end{array}$ & $\begin{array}{l}\mathrm{DP}(66) \\
\mathrm{P}(34) \\
\mathrm{N}(0)\end{array}$ & 1634 & 1808 & 1167 & 745 \\
\hline $3 \mathbf{h}^{e}$ & $m-\mathrm{Cl}$ & & $\mathrm{CH}$ & $\begin{array}{l}\mathrm{DP}(10) \\
\mathrm{P}(89) \\
\mathrm{N}(1)\end{array}$ & $\begin{array}{l}\mathrm{DP}(15) \\
\mathrm{P}(85) \\
\mathrm{N}(0)\end{array}$ & $\begin{array}{l}\mathrm{DP}(90) \\
\mathrm{P}(10) \\
\mathrm{N}(0)\end{array}$ & 1419 & 1032 & 113 & 199 \\
\hline CLT & - & - & - & $\begin{array}{l}P(5) \\
N(95)\end{array}$ & $\begin{array}{l}\mathrm{P}(8) \\
\mathrm{N}(92)\end{array}$ & $\begin{array}{l}\mathrm{P}(81) \\
\mathrm{N}(19)\end{array}$ & 550 & 490 & 60 & 250 \\
\hline $\mathrm{CQ}$ & & & & $\begin{array}{l}\mathrm{DP}(8) \\
\mathrm{P}(92) \\
\mathrm{N}(0)\end{array}$ & $\begin{array}{l}\mathrm{DP}(12) \\
\mathrm{P}(88) \\
\mathrm{N}(0)\end{array}$ & $\begin{array}{l}\mathrm{DP}(87) \\
\mathrm{P}(12) \\
\mathrm{N}(0)\end{array}$ & 22 & 280 & 10 & 260 \\
\hline
\end{tabular}

\footnotetext{
${ }^{a}$ Percentage of ionic form in brackets; $\mathrm{TP}=$ triprotonated form; $\mathrm{DP}=$ diprotonated form; $\mathrm{P}=$ protonated form; and $\mathrm{N}=$ neutral form $(\mathrm{ACD} / \mathrm{pKa} \mathrm{DB}$ version 10.00 software - Advanced Chemistry Development, Inc., Toronto, Canada-). ${ }^{b} \mathrm{IC}_{50} \mathrm{~S}$ are the mean of at least three determinations. Standard errors were all within $10 \%$ of the mean; n.a. $=$ Not Active $\left(\mathrm{IC}_{50}>10 \mu \mathrm{M}\right) .{ }^{c} \mathrm{CQ}-\mathrm{S}$ clone. ${ }^{d} \mathrm{CQ}-\mathrm{R}$ clone. ${ }^{e}$ Ref. 6.
}

presence of sodium hydride, to afford nitriles $\mathbf{2 5} \mathbf{a}$ and $\mathbf{2 5} \mathbf{b}$, respectively, which were subsequently converted into the corre- sponding ketone derivatives $\mathbf{2 6 a}, \mathbf{b} .^{19}$ Following the synthetic procedure already described, Grignard reaction, followed by 


\section{Scheme $1^{a}$}<smiles>O=C(c1ccc(CBr)cc1)c1cccc(C(=O)c2cccc(CN3CCN(C(=O)OCc4ccccc4)CC3)c2)c1</smiles><smiles>[R]Cc1ccc(C(O)c2cccc(Cl)c2)cc1</smiles>

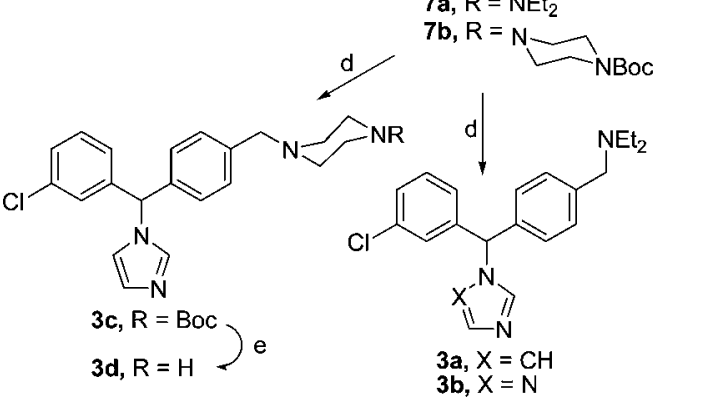

${ }^{a}$ Reagents and conditions: (a) $\mathrm{N}$-Boc-piperazine, $\mathrm{Et}_{3} \mathrm{~N}, \mathrm{MeCN}, 0{ }^{\circ} \mathrm{C}, 2 \mathrm{~h}$; (b) $\mathrm{NaBH}_{4}, \mathrm{THF} / \mathrm{H}_{2} \mathrm{O} 2: 1,80{ }^{\circ} \mathrm{C}, 1.5 \mathrm{~h}$; (c) $\mathrm{Mg}$ turnings, THF, $80^{\circ} \mathrm{C}$; (d) (i) $\mathrm{SOCl}_{2}, \mathrm{DCM}, 0^{\circ} \mathrm{C}$ to rt, $4 \mathrm{~h}$; (ii) imidazole (for 3a,c) or $1 \mathrm{H}-1,2,4$-triazole (for 3b), $\mathrm{Et}_{3} \mathrm{~N}, \mathrm{MeCN}, 0$ to $80^{\circ} \mathrm{C}, 4 \mathrm{~h}$; (e) TFA, DCM, $0-5{ }^{\circ} \mathrm{C}, 3 \mathrm{~h}$.

Scheme $2^{a}$

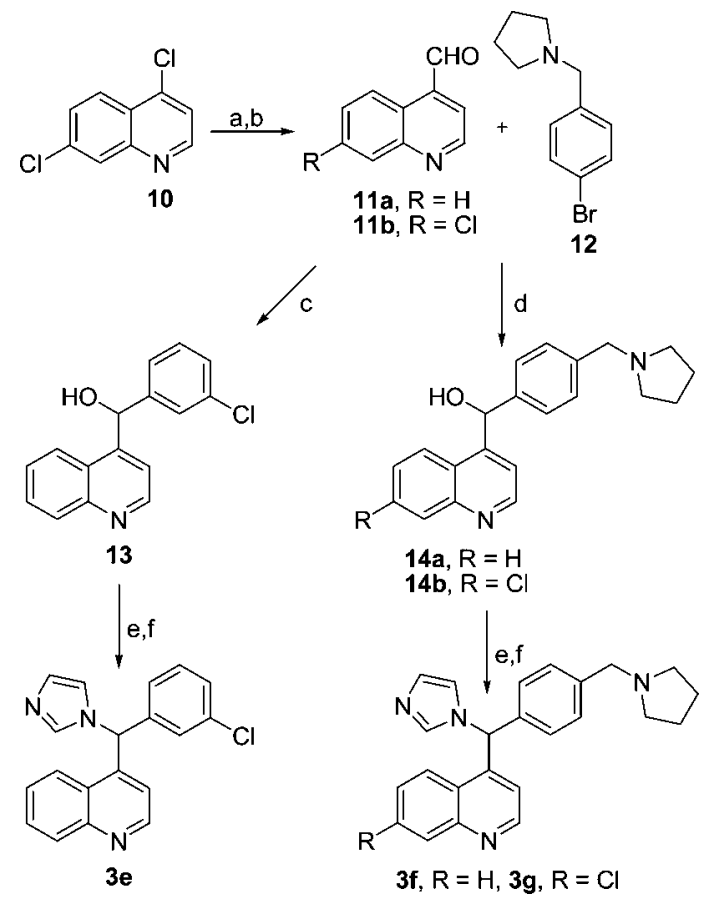

${ }^{a}$ Reagents and conditions: (a) $\mathrm{MeMgBr}$, [1,2-bis(diphenylphosphino)ethane]dichloronickel(II), $\mathrm{Et}_{2} \mathrm{O}, 0{ }^{\circ} \mathrm{C}$ to $\mathrm{rt}, 24 \mathrm{~h}$; (b) $\mathrm{SeO}_{2}$, bromobenzene, $170-175^{\circ} \mathrm{C}, 18 \mathrm{~h}$; (c) 3-chlorophenylmagnesium bromide, THF, $80^{\circ} \mathrm{C}$, $6 \mathrm{~h}$; (d) $n$-BuLi, THF, $-78^{\circ} \mathrm{C}$ to rt, $24 \mathrm{~h}$; (e) $\mathrm{SOCl}_{2}, \mathrm{DCM}, 0{ }^{\circ} \mathrm{C}$ to rt, $5 \mathrm{~h}$; (f) imidazole sodium salt, DMF, $80^{\circ} \mathrm{C}, 3 \mathrm{~h}$.

chlorination of the resulting carbinols 27a,b and subsequent treatment with imidazole and triethylamine, afforded the desired compounds $\mathbf{4 m , n}$.

\section{Results and Discussion}

1. In Vitro Antimalarial Activity and Structure-Activity Relationship. All synthesized compounds were tested in vitro against a series of $P f$ strains, namely, the CQ-sensitive
Scheme $3^{a}$

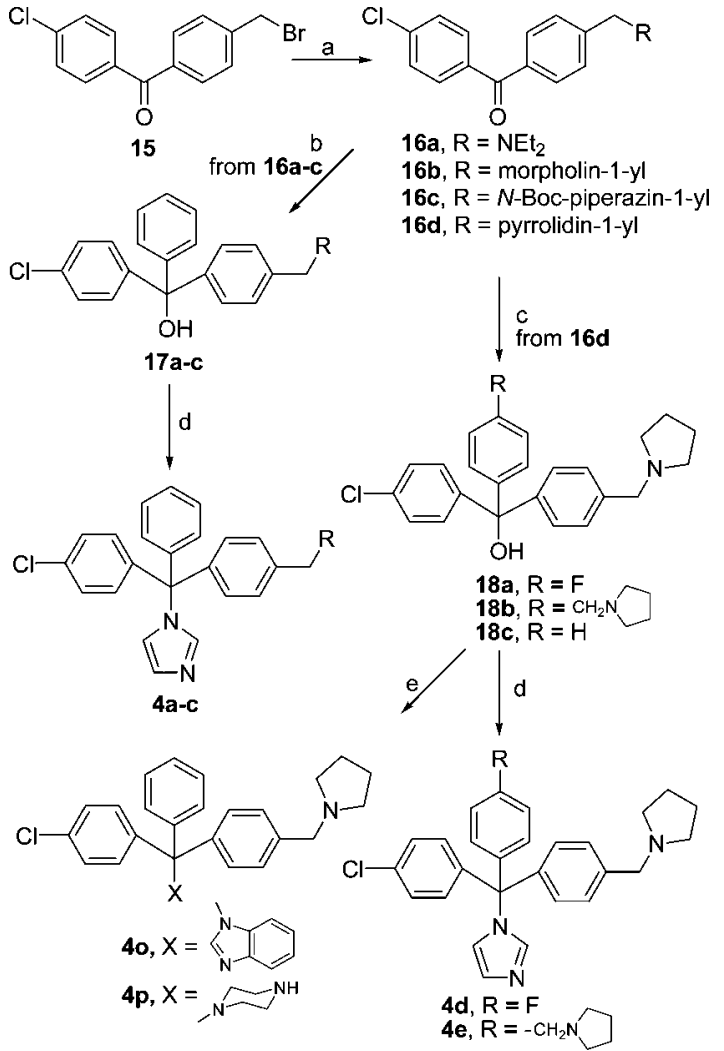

${ }^{a}$ Reagents and conditions: (a) $\mathrm{Et}_{2} \mathrm{NH}$ (for 16a), morpholine (for 16b), $N$-Boc-piperazine (for 16c), $\mathrm{Et}_{3} \mathrm{~N}, \mathrm{MeCN}, 0{ }^{\circ} \mathrm{C}, 1 \mathrm{~h}$; (b) phenylmagnesium bromide, THF, $80^{\circ} \mathrm{C}, 6 \mathrm{~h}$; (c) $p$-fluorobromobenzene (for 18a), 12 (for 18b), Mg, THF, $80{ }^{\circ} \mathrm{C}, 6 \mathrm{~h}$; (d) (i) $\mathrm{SOCl}_{2}, \mathrm{DCM}, 0$ to $45^{\circ} \mathrm{C}, 4 \mathrm{~h}$, (ii) imidazole, $\mathrm{Et}_{3} \mathrm{~N}, \mathrm{MeCN}, 0$ to $80{ }^{\circ} \mathrm{C}, 4 \mathrm{~h}$; (e) (i) $\mathrm{SOCl}_{2}, \mathrm{DCM}, 0{ }^{\circ} \mathrm{C}$ to rt, $4 \mathrm{~h}$, (ii) benzimidazole (for 4o), piperazine (for $4 \mathbf{p}$ ), $\mathrm{Et}_{3} \mathrm{~N}, \mathrm{MeCN}, 0$ to 80 ${ }^{\circ} \mathrm{C}, 4 \mathrm{~h}$.

\section{Scheme $4^{a}$}

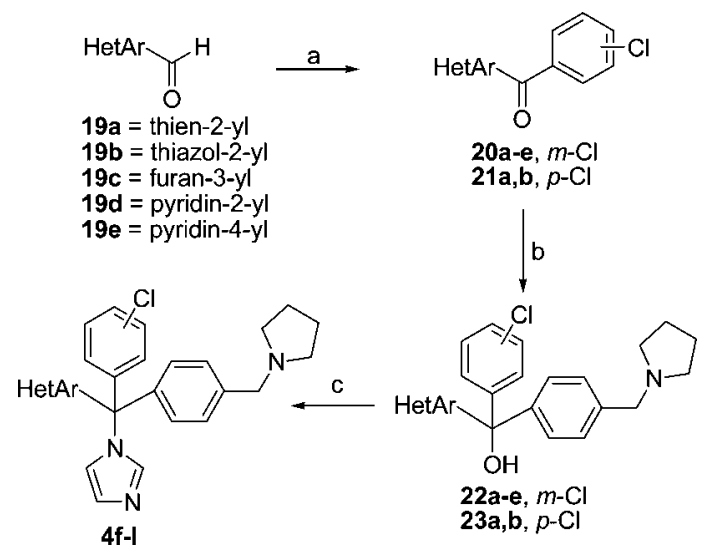

${ }^{a}$ Reagents and conditions: (a) $m$-chlorophenylmagnesium bromide or p-chlorophenylmagnesium bromide, THF, $80^{\circ} \mathrm{C}, 3 \mathrm{~h}$; (b) 12, Mg, THF, 80 ${ }^{\circ} \mathrm{C}, 6 \mathrm{~h}$; (c) (i) $\mathrm{SOCl}_{2}, \mathrm{DCM}, 0{ }^{\circ} \mathrm{C}$ to rt, $4 \mathrm{~h}$; (ii) imidazole, $\mathrm{Et}_{3} \mathrm{~N}, \mathrm{MeCN}$, 0 to $80{ }^{\circ} \mathrm{C}, 4 \mathrm{~h}$.

(CQ-S) D10 and 3D7 and the CQ-resistant (CQ-R) W2 and K1 strains. The antimalarial activity $\left(\mathrm{IC}_{50}, \mathrm{nM}\right)$ was quantified as inhibition of parasite growth, measured with the production of parasite lactate dehydrogenase (D10 and W2 strains, asynchronous culture) or the incorporation of $\left[{ }^{3} \mathrm{H}\right]$-hypoxanthine (3D7 and $\mathrm{K} 1$ strains, synchronous culture). Results are reported in Tables 1,2.

Based on the above-mentioned CLT properties, we used its scaffold to develop novel antimalarial agents characterized by 


\section{Scheme $5^{a}$}<smiles>COc1ccnc2cc(Cl)ccc12</smiles><smiles>[R]c1ccc(C(C#N)c2ccnc3cc(Cl)ccc23)cc1</smiles><smiles>C1CCNC1</smiles><smiles>[Y]Cc1ccc(O)cc1</smiles><smiles>C=CCC(C=CC)c1ccnc2cc(Cl)ccc12</smiles>

(2) 7a,b

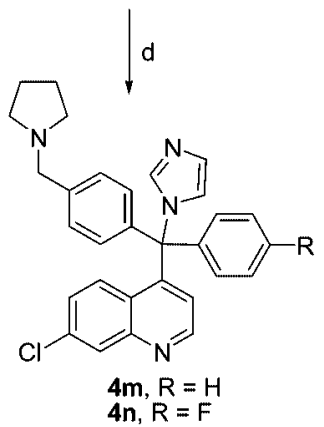

${ }^{a}$ Reagents and conditions: (a) phenylacetonitrile (for 25a), 4-fluorophenylacetonitrile (for $\mathbf{2 5 b}$ ), $\mathrm{NaH}\left(60 \%\right.$ in mineral oil), THF, $70^{\circ} \mathrm{C}, 30 \mathrm{~min}$; (b) $\mathrm{NaH}\left(60 \%\right.$ in mineral oil), $\mathrm{O}_{2}$, THF, rt, $2 \mathrm{~h}$; (c) 12, Mg, THF, $80^{\circ} \mathrm{C}$, $6 \mathrm{~h}$; (d) (i) $\mathrm{SOCl}_{2}, \mathrm{DCM}, 0$ to $45^{\circ} \mathrm{C}, 24 \mathrm{~h}$, (ii) imidazole, $\mathrm{Et}_{3} \mathrm{~N}, \mathrm{MeCN}, 0$ to $80{ }^{\circ} \mathrm{C}, 4 \mathrm{~h}$.

the selective binding to free heme but lacking interaction with a definite $P f$ or host target protein (to minimize resistance), with improved antimalarial potency and pharmacological profile over CLT and reduced side effects. To achieve activity against both CQ-S and CQ-R Pf strains, we reasoned that an effective antimalarial should rapidly accumulate and be activated inside the microenvironment of the parasite FV (i.e., $\mathrm{pH} 5.5$; redox milieu $-250 \mathrm{mV}$; presence of free heme), where the spontaneous oxidation of hemoglobin-derived $\mathrm{Fe}$ (II) heme to $\mathrm{Fe}$ (III) heme promotes the formation of superoxide ions generating $\mathrm{H}_{2} \mathrm{O}_{2}$ and hydroxyl radicals. On these bases, our design strategy focused on novel antimalarials characterized by improved penetration into the FV and with appropriate electronic features that would generate radical intermediates in the $P f \mathrm{FV}$ environment. Starting from CLT structure, to increase FV accumulation, we introduced an extra protonatable function, while to modulate the interaction with free heme and the generation and stabilization of a radical intermediate, we investigated the effect of different heme complexing groups and of different aromatic substituents.

(a). Diarylmethyl versus Triarylmethyl Derivatives. We dismantled the structure of CLT and consequently synthesized the diphenylmethyl derivatives $\mathbf{3 a}-\mathbf{g}$ (Table 1) to identify the minimal structural requirement for antimalarial activity, which could subsequently be optimized to meet the pharmacodynamic and pharmacokinetic prerequisites to enter into further development. Compounds $\mathbf{3 a}-\mathbf{g}$ were found to be significantly less potent than CLT against both CQ-S and CQ-R Pf strains (Table 1). According to our hypothesized mechanism of action, the lower activity of the diaryl analogues with respect to CLT (triaryl system) can be explained in terms of interference with the formation and stabilization of a radical intermediate, critical for antimalarial activity. Indeed, the potency strongly increased when an additional phenyl ring or an appropriate heterocycle was introduced ( $\mathbf{3 h}$ vs $\mathbf{4 q}$ and $\mathbf{4 g}, \mathbf{3 g}$ vs $\mathbf{4 m}$, Tables 1 and 2 ), indicating that a triarylmethyl moiety represents the minimal feature for high antimalarial activity.

(b). Key Role of the Heme Complexing Group. Following our design hypothesis, the imidazole ring, protonated at the FV $\mathrm{pH}$ and having the dual role of interacting with free heme and of being the substrate for the redox reaction generating a trityl radical, was the heme interacting group of choice. ${ }^{9,12,13,20}$ In the diarylmethyl series, introduction of a triazole ring resulted in the loss of antimalarial activity with respect to the imidazole analogue (3a vs 3b), and in the triarylmethyl series, a similar effect was observed when a piperazine ring was introduced (4p vs 2). This confirms that the introduction of groups capable of chelating iron but unable to promote the formation of the radical intermediate are detrimental for the activity. Indeed, the triazole nitrogen-centered radical is destabilized through the unfavorable dipole-dipole interaction of the radical electron with lone pair electrons of the adjacent nitrogen atom. ${ }^{20}$ Moreover, the triazole moiety is not protonated at the $\mathrm{FV} \mathrm{pH}$, causing a decreased accumulation of the compound. On the other hand, the piperazine nitrogen is protonated at the $\mathrm{FV} \mathrm{pH}$ but is unable to generate a radical through a conjugation-mediated electron transfer. Accordingly, $4 \mathbf{o}$ was found to be more potent than $\mathbf{4 p}$ but slightly less potent than $\mathbf{2}$ because its benzimidazole ring is able to chelate iron and to generate free radicals ${ }^{21}$ but is less protonated at $\mathrm{FV} \mathrm{pH}$ than imidazole. This finding further supports our design hypothesis. ${ }^{6}$

(c). Protonatable Lateral Chain. Introduction of an extra protonatable chain was a key finding to highly improve potency and FV accumulation of the novel antimalarials ( 2 vs CLT). ${ }^{6}$ The antimalarial activity could also be modulated by varying the nature of the protonatable lateral chain. Substitution of the pyrrolidine group by a piperazine led to a moderate increase of antimalarial activity against asynchronous D10 and W2 strains (3d vs $\mathbf{3 h}$ and $\mathbf{4 c}$ vs $\mathbf{2}$ ). This data could be explained taking into consideration that also piperazine is able to form complexes with iron, ${ }^{5 a}$ thus suggesting that an additional metal interaction point, as in $\mathbf{3 d}$ and $\mathbf{4 c}$, could be responsible of the increased in vitro antimalarial activity with respect to $\mathbf{2}$ (a mechanism already exploited by other antimalarial agents used for iron chelation therapy ${ }^{22}$ ). In the triarylmethyl series, the introduction of a diethylamino group (4a) resulted in a decreased activity against both CQ-S strains, while a 10-fold potentiation was observed against the K1 CQ-R strain (4a vs 2). On the other hand, the presence of the less protonatable morpholine ring (4b) reduced the antimalarial activity with respect to 2 against both D10 and W2 strains. Such a dependence of antimalarial activity from the nature of the protonatable lateral chain has been extensively described for CQ derivatives, in which introduction of bulkier groups at the distal nitrogen generally resulted in an increased activity against CQ-R strains ${ }^{23}$ and is probably suggestive of a possible altered interaction with a protein transporter, which has been hypothesized as a mechanism leading to CQ-resistance.

(d). Halogen vs Methoxy Substituents at the Trityl System. Electron-donating and electron-withdrawing substituents at the trityl system differently affect the capability of the system to generate and stabilize radical intermediates and, by consequence, the antimalarial potency of the corresponding compounds. In general, electron-donating or -withdrawing groups may significantly modulate the reactivity of triarylmethyls and, consequently, the pharmacological properties. In fact, while the $p$-Cl substituent was responsible for a fine-tuning 
Table 2. Antiplasmodial Activity of Compounds $4 \mathbf{a}-\mathbf{r}$

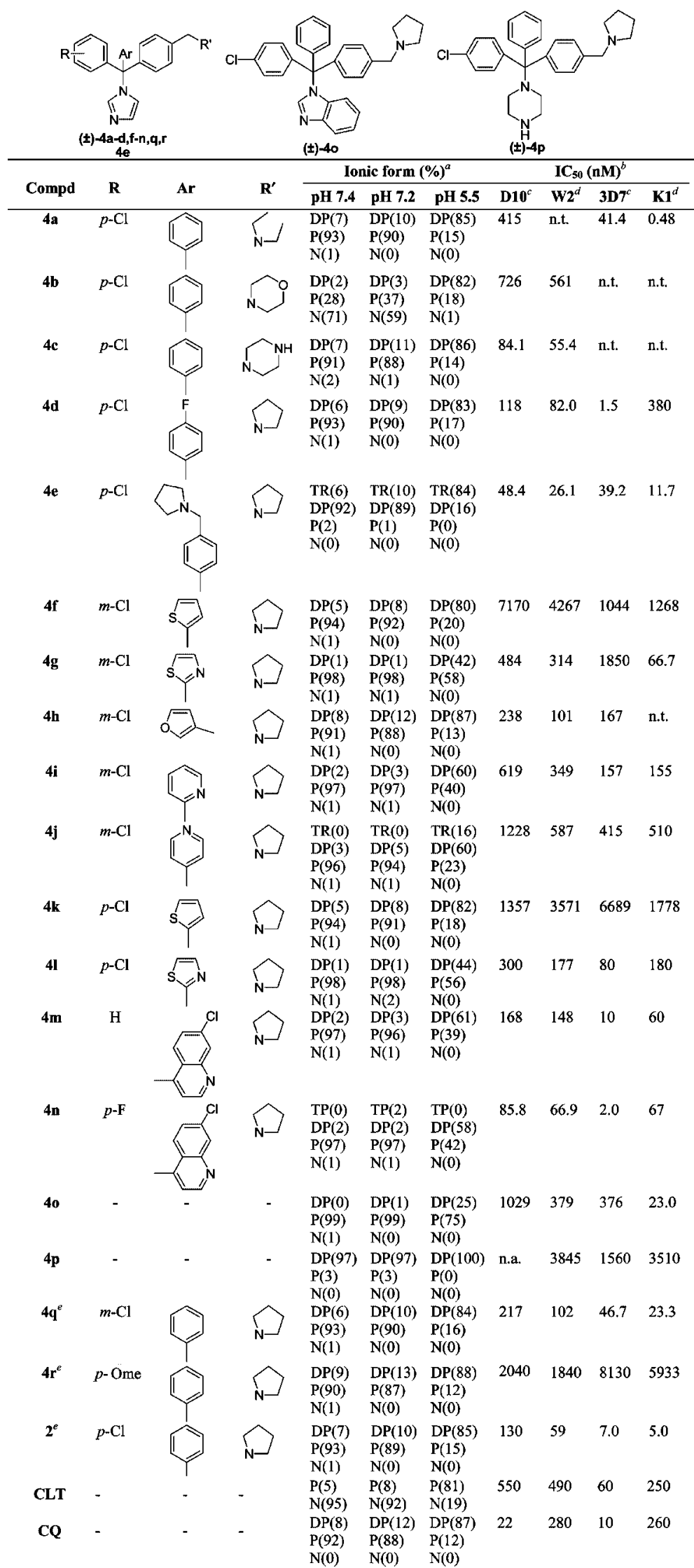

${ }^{a}$ Percentage of ionic form in brackets; $\mathrm{TP}=$ triprotonated form; $\mathrm{DP}=$ diprotonated form; $\mathrm{P}=$ protonated form; and $\mathrm{N}=$ neutral form $(\mathrm{ACD} / \mathrm{pKa} \mathrm{DB}$ version 10.00 software - Advanced Chemistry Development, Inc., Toronto, Canada-). ${ }^{b} \mathrm{IC}_{50} \mathrm{~S}$ are the mean of at least three determinations. Standard errors were all within $10 \%$ of the mean; n.t. $=$ Not Tested. ${ }^{c}$ CQ-S clone. ${ }^{d}$ CQ-R clone. ${ }^{e}$ Ref. 6. 
Table 3. AM1 Partial Charges of the $\mathrm{C} \alpha$ (ipso Phenyl Carbons) and the Central Methine Carbon of $\mathbf{2}, \mathbf{4 d}-\mathbf{4 h}, \mathbf{4 q}$, and $\mathbf{4 r}$ in their Prevalent Ionic Forms at Cytoplasmatic (7.2) and FV (5.5) $\mathrm{pH}$

\begin{tabular}{|c|c|c|c|c|c|c|c|c|}
\hline \multirow[b]{2}{*}{ cmpd } & \multicolumn{2}{|c|}{$\mathrm{C} \alpha 1$} & \multicolumn{2}{|c|}{$\mathrm{C} \alpha 2$} & \multicolumn{2}{|c|}{$\mathrm{C} \alpha 3$} & \multicolumn{2}{|c|}{$\begin{array}{c}\text { central } \\
\text { methine carbon }\end{array}$} \\
\hline & $\mathrm{P}^{a}$ & $\mathrm{DP}^{a}$ & $\mathrm{P}$ & DP & $\mathrm{P}$ & DP & $\mathrm{P}$ & DP \\
\hline 2 & -0.11 & -0.15 & -0.12 & -0.16 & -0.03 & -0.06 & +0.23 & +0.23 \\
\hline $4 d$ & -0.11 & -0.15 & -0.14 & -0.18 & -0.03 & -0.06 & +0.23 & +0.24 \\
\hline $4 e^{b}$ & -0.12 & -0.18 & -0.07 & -0.09 & -0.05 & -0.08 & +0.22 & +0.24 \\
\hline 4f & -0.11 & -0.14 & -0.45 & -0.54 & -0.04 & -0.07 & +0.27 & +0.28 \\
\hline $4 g$ & -0.10 & -0.15 & -0.36 & -0.45 & -0.04 & -0.07 & +0.26 & +0.28 \\
\hline $4 h$ & -0.10 & -0.14 & -0.19 & -0.26 & -0.05 & -0.07 & +0.26 & +0.28 \\
\hline $4 n$ & -0.14 & -0.18 & -0.06 & -0.11 & -0.04 & -0.06 & +0.23 & +0.24 \\
\hline $4 q$ & -0.10 & -0.13 & -0.11 & -0.16 & -0.04 & -0.07 & +0.23 & +0.24 \\
\hline $4 r$ & -0.15 & -0.20 & -0.11 & -0.15 & -0.04 & -0.06 & +0.24 & +0.24 \\
\hline
\end{tabular}

${ }^{a} \mathrm{P}=$ protonated form; $\mathrm{pH} 7.2 ; \mathrm{DP}=$ diprotonated form; $\mathrm{pH} 5.5$. ${ }^{b}$ Compound $4 \mathrm{e}$ can only exist in the diprotonated $(\mathrm{pH} 7.2)$ and triprotonated (pH 5.5) form.

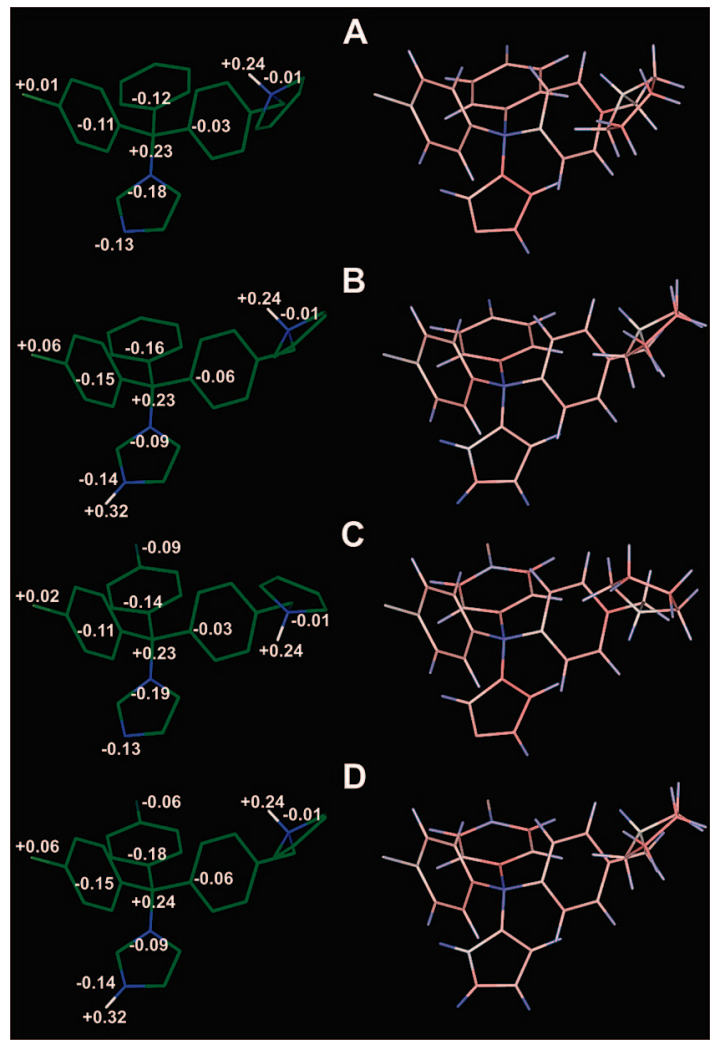

Figure 1. Resulting MOPAC (AM1) conformers of $\mathbf{2}$ and $\mathbf{4 d}$ in their prevalent ionic forms at the cytoplasmatic $\mathrm{pH}$ (A and $\mathrm{C}$, respectively) and at the FV pH (B and D, respectively). Left: the compounds are colored by atom type (green for $\mathrm{C}$, white for $\mathrm{H}$, blue for $\mathrm{N}$, light-green for $\mathrm{Cl}$, and dark-green for $\mathrm{F}$ ). AM1 partial charges of $\mathrm{C} \alpha$ (ipso phenyl carbons), central methine carbon, heteroatoms, and protonatable groups are showed. All hydrogens, except those of protonable nitrogens, have been omitted for clarity. Right: the compounds are colored by AM1 charge distribution (the atoms are colored from red $(-0.5)$ to blue $(+0.5)$ depending upon their partial charge value).

of activity against CQ-S and CQ-R strains (2 vs $\mathbf{4 q}$ ), a dramatic decrease of activity was observed when the electron-withdrawing chlorine atom was replaced by the electron-donating methoxy group (4r vs 2). AM1 quantomechanical calculation showed that the partial charge distribution at the trityl system in the monoprotonated and diprotonated forms of both $\mathbf{2}$ and $\mathbf{4 r}$ was highly affected by the $p$-substituent (Table 3 ). In $\mathbf{4 r}$, the presence of the $p$-methoxy-substituted phenyl ring determined an increased electron density at the C $\alpha 1$ (ipso phenyl carbon 1) linked to the trityl central methine carbon (Chart 1), which is detrimental for the formation of the intermediate trityl radical.

We also explored the effect produced by the introduction of fluorine atoms at the trityl system to increase the metabolic stability. When a $p$-fluorine substituent was introduced, the resulting compound $\mathbf{4 d}$ showed antimalarial properties similar to 2 against asynchronous strains D10 and W2 and the synchronous CQ-S strain 3D7. However, it proved to be lesspotent against $\mathrm{K} 1$. This could be explained considering that each Pf strain, sensitive or not to CQ, may present a different chemical environment at the FV level (i.e., $\mathrm{pH}$ value associated to CQ resistance ${ }^{24}$ ). Thus, in the case of $\mathbf{4 d}$, the efficacy on the different strains can be explained by taking into consideration the electron distribution of the monoprotonated and diprotonated forms whose relative amount is determined by the different FV environment of each strain (Table 2). Accordingly, the diprotonated form of $\mathbf{4 d}$ has a partial charge distribution disfavoring radical formation with respect to the corresponding monoprotonated form (Figure 1 and Table 3).

(e). Modulation of the Electronic Features of the Triarylmethyl System: Effect of Five-Membered Heterocycles. To further explore the role played by specific electronic features in modulating the formation/stabilization of a radical intermediate and the antimalarial activity of these polycyclic antimalarials, we replaced one aromatic group by five-membered heterocycles and their partial charge distribution was calculated by AM1 quantomechanical methods. Even though it has been demonstrated that replacement of a phenyl by a thiophene does not change dramatically the reactivity of the trityl system, we observed in our series of compounds (five-membered heterocycles combined to the presence of an imidazole ring) significantly different electron distributions in the polyaromatic systems taken into consideration. Indeed, as shown in Figure 2 and Table 3, by comparison of the electron distribution of $\mathbf{4 q}$, to the one of the thiophene (4f), thiazole (4g), and furan (4h) derivatives, an increased electron density at the $\mathrm{C} \alpha$ (ipso aryl carbons, Chart 1) was observed, thus reducing the generation of a radical intermediate and lowering the antimalarial potency with respect to $\mathbf{4 q}$. In general, the increased polarization and electron density of the heterocycles introduced was inversely related to their antimalarial potency (Figure 2). In fact, the thiophene derivative $\mathbf{4 f}$, which displayed the higher electron density at $\mathrm{C} \alpha$ was the least potent compound of the subseries, while activity increased introducing a furan or a thiazole ring, following the rank order of potency $\mathbf{4 h}>\mathbf{4 g}>\mathbf{4 f}$. The same $\mathrm{SAR}$ was observed for the corresponding $p$-Cl analogues $4 \mathbf{k}$ and $\mathbf{4 l}$. The higher activity of $\mathbf{4 l}$ compared to $\mathbf{4 g}$ confirmed the fine-tuning of the antimalarial activity operated by the $p-\mathrm{Cl}$ substituent even in this heterocyclic series of analogues.

(f). Pyridine versus Quinoline: Increasing the Antimalarial Potency. When a 4-pyridyl (4j) or a 2-pyridyl (4i) heterocycles were taken into consideration, a lower antimalarial activity with respect to $\mathbf{4 q}$ was observed. Although the replacement of a phenyl ring by a piridyl ring in a triphenylmethyl radical does not change dramatically its stability, however, the pyridyl group delocalizes radicals less than the phenyl ring. ${ }^{14}$ On these bases, to increase the ability to stabilize a radical intermediate and, consequently, the antimalarial activity, we planned to replace the 4-pyridyl by a 7-chloroquinolin-4-yl system (a pyridine with a fused $4-\mathrm{Cl}$ benzo group at $\mathrm{C} 2-\mathrm{C} 3$ ), which stabilizes the radical by a higher $\pi$ delocalization. Accordingly, the 7-Cl-quinoline derivative $\mathbf{4 m}$, although lacking the favorable electron-withdrawing substituent on the phenyl ring (see paragraph (d), Halogen vs Methoxy Substituents at 


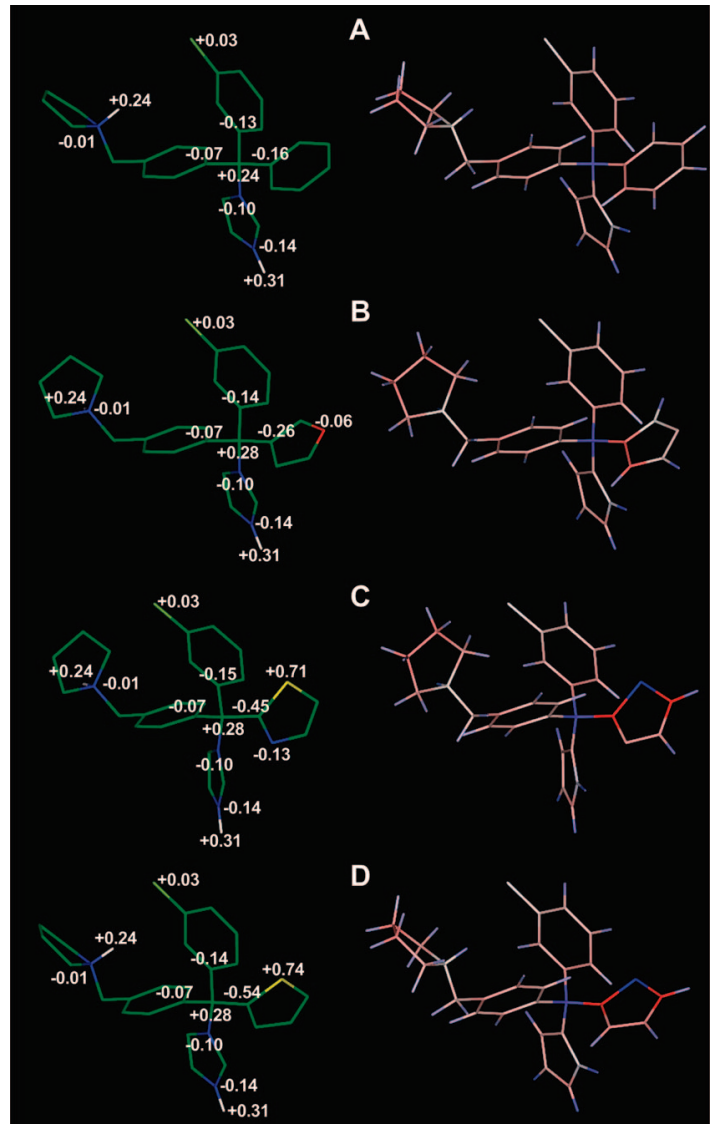

Figure 2. Resulting MOPAC (AM1) conformers of $\mathbf{4 q}(\mathrm{A}), \mathbf{4 h}(\mathrm{B})$, $\mathbf{4 g}(\mathrm{C})$, and $\mathbf{4 f}(\mathrm{D})$ in their prevalent ionic forms at the FV $\mathrm{pH}$. Left: the compounds are colored by atom type (green for $\mathrm{C}$, white for $\mathrm{H}$, blue for $\mathrm{N}$, light-green for $\mathrm{Cl}$, red for $\mathrm{O}$, and yellow for $\mathrm{S}$ ). AM1 partial charges of $\mathrm{C} \alpha$ (ipso phenyl carbons), central methine carbon, heteroatoms, and protonatable groups are showed. All hydrogens, except those of the protonable nitrogens, have been omitted for clarity. Right: the compounds are colored by AM1 charge distribution (the atoms are colored from red $(-0.5)$ to blue $(+0.5)$ depending upon their partial charge value).

the Trityl System), was endowed with a higher antimalarial activity against both CQ-R and CQ-S strains than $\mathbf{4 j}$, in perfect agreement with its electronic properties. The higher potency of 4m might also be explained taking into account that the 7-chloroquinoline system may interact with heme, competing with the imidazole. According to the SARs discussed in paragraph (d), a further increase of activity was then obtained by introducing a $p$-F substituent (4n) at the phenyl ring of $\mathbf{4 m}$ (4n vs $\mathbf{4 m}$ ). Nevertheless, contrary to what was observed for compound $\mathbf{4 d}$, the activity on the $\mathrm{K} 1$ strain of $\mathbf{4 n}$ is preserved (Table 2), according to its partial charge distribution (Table 3).

(g). Achiral Antimalarials. Most of the compounds designed and tested incorporate a chiral center that, when resolved into the pure enantiomers, may cause an increase of synthetic costs, thus compromising the potentiality of industrial development. Consequently, to improve the drugability of these antimalarials, we specifically removed the chiral center by introducing an extra protonatable pyrrolidinylmethyl system (4e), maintaining significant $\mathrm{FV}$ penetration and accumulation and ameliorating the solubility $(2 \operatorname{logD}$ : pH $7.4=3.33, \mathrm{pH} 7.2=3.13$, pH $5.5(\mathrm{FV})$ $=1.72 ; 4 \mathrm{e} \log \mathrm{D}: \mathrm{pH} 7.4=1.56, \mathrm{pH} 7.2=1.40, \mathrm{pH} 5.5(\mathrm{FV})$ $=0.67)$. Similar to 2 , compound $4 \mathrm{e}$ was found to be highly potent against all tested strains and was more potent against CQ-R than CQ-S strains. In addition, the presence of two pyrrolidinylmethyl substituents decreased the electron density

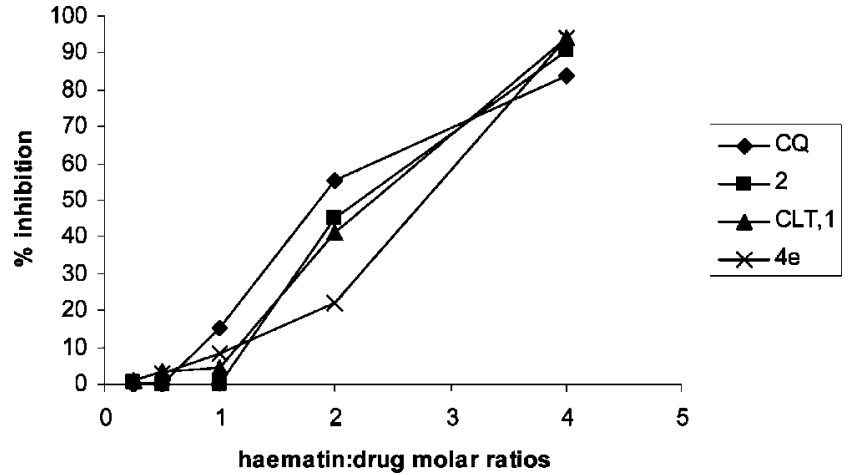

Figure 3. Hematin inhibitory activity assay of compounds CQ, CLT, 2 , and $4 \mathbf{e}$.

Table 4. $\beta$-Hematin Inhibitory Activity Assay of Compounds 4e, 2, CLT (1), and CQ

\begin{tabular}{lc}
\hline $\mathrm{cmpd}$ & $\mathrm{IC}_{50}{ }^{a}$ \\
\hline $\mathbf{4 e}$ & 2.85 \\
$\mathbf{2}$ & 2.53 \\
$\mathrm{CLT}, \mathbf{1}$ & 2.50 \\
CQ & 1.69 \\
\hline
\end{tabular}

${ }^{a}$ The $\mathrm{IC}_{50}$ represents the molar equivalents of compound, relative to hemin, that inhibit $\beta$-hematin formation by $50 \%$. Data are the mean of three different experiments in triplicate. Standard errors were all within $10 \%$ of the mean.

at $\mathrm{C} \alpha$ (Chart 1; AM1 calculations, Table 3), increasing the stabilization of a putative trityl radical intermediate responsible for antimalarial activity. These data together with the high potency of $\mathbf{4} \mathbf{e}$ further confirm the hypothesis of the generation of a radical intermediate for this class of antimalarials. Compound $\mathbf{4} \mathbf{e}$ was thus selected for further biological investigation (see paragraph 5).

2. $\boldsymbol{\beta}$-Hematin Inhibitory Activity Assay. Two of the most active compounds ( 2 and $\mathbf{4 e}$ ) were screened for inhibition of $\beta$-hematin formation by using the $\beta$-hematin inhibitory activity (BHIA) assay. ${ }^{25}$ Both compounds showed a dose-dependent inhibition of $\beta$-hematin formation (Figure 3 and Table 4). Although compounds $\mathbf{2}$ and $\mathbf{4 e}$ were found much more potent than CLT on different $P f$ strains, their in vitro BHIA was found to be very similar to that of CLT, suggesting a similar interaction with free heme. On the other hand, although with a similar protonation state, CQ and $\mathbf{2}$ (Table 2) differ for their in vitro antimalarial potency $(\mathbf{2}>>\mathrm{CQ})$ and their inhibitory potency in the BHIA assay (CQ $>>2$ ). This suggests that other physicochemical characteristics of the molecules and/or a different mechanism of action, besides inhibition of hemozoin formation, may be responsible for killing the parasite. Compound $4 \mathbf{e}$, triprotonated at the $\mathrm{FV} \mathrm{pH}$ (Table 2), proved to be even less potent than CQ and $\mathbf{2}$ in the BHIA assay, while maintaining a high potency against CQ-S and CQ-R strains.

3. Antifungal Activity. Selected compounds were also tested to measure their antifungal activity (Table 1, Supporting Information (SI)), as the lack of antifungal activity could be predictive for a low propensity to interfere with cytochrome P450 activity. CLT and the other antifungal azoles are known to exert their activity by interfering with fungal cytochrome P450s (such as 14-LD), and some of their side effects are linked to interference with human cytochromes. On the basis of our docking studies and bioinformatic analysis, the basic side chain of 2 and analogues, besides to increase the pharmacokinetic properties with respect to CLT, were also designed to improve selectivity for free heme over heme as cytochromes P450 prosthetic group. To hit this mark, CLT was subjected to flexible 
Table 5. Cytotoxicity Assays for Selected Compounds

\begin{tabular}{lllll}
\hline & \multicolumn{3}{c}{$\mathrm{TC}_{50}(\mu \mathrm{M})^{a}$} \\
\cline { 2 - 5 } cmpd & $\begin{array}{l}\text { NSO } \\
\text { cells }^{b}\end{array}$ & $\begin{array}{c}\text { Daudi } \\
\text { cells }^{c}\end{array}$ & $\begin{array}{c}\text { Normal human } \\
\text { lymphocytes }\end{array}$ & $\begin{array}{c}\mathrm{KB} \\
\text { cells }^{e}\end{array}$ \\
\hline $\mathbf{2}$ & 51.5 & 58.5 & 70.3 & n.t. $^{f}$ \\
$\mathbf{4 b}$ & 16.0 & 15.6 & 13.3 & n.t. \\
$\mathbf{4 c}$ & 16.2 & 15.8 & 13.7 & n.t. \\
$\mathbf{4 d}$ & n.t. & n.t. & n.t. & 8.2 \\
$\mathbf{4 e}$ & 47.0 & 58.7 & 68.5 & n.t. \\
$\mathbf{4 g}$ & 52.9 & 57.5 & 80.5 & n.t. \\
$\mathbf{4 i}$ & n.t. & n.t. & n.t. & 27.2 \\
$\mathbf{4 1}$ & n.t. & n.t. & n.t. & 64.2 \\
$\mathbf{4 m}$ & n.t. & n.t. & n.t. & 51.8 \\
$\mathbf{4 n}$ & n.t. & n.t. & n.t. & 33.0 \\
$\mathbf{4 p}$ & n.t. & n.t. & n.t. & 20.9 \\
$\mathbf{C L T}$ & n.t. & n.t. & n.t. & 88.1 \\
$\mathbf{C Q}$ & n.t. & n.t. & n.t. & 207.0 \\
\hline
\end{tabular}

${ }^{a}$ Standard errors never exceeded $5 \%$ of the reported values. ${ }^{b}$ Plasmocytoma murine cell line. ${ }^{c}$ Human lymphoblastoid cell line. ${ }^{d}$ Normal human lymphocytes PHA-stimulated. ${ }^{e}$ Human carcinoma of the nasopharynx cell line. ${ }^{f}$ n.t. $=$ not tested.

Table 6. In Vivo Antimalarial Activity of Selected Compounds against $P$. berghei and P. chabaudi after Oral Administration

\begin{tabular}{lcc}
\hline & \multicolumn{2}{c}{$\%$ suppression on day $4^{a}(\mathrm{mg} / \mathrm{Kg})$} \\
\cline { 2 - 3 } cmpd & P. chabaudi AS & P. berghei ANKA \\
\hline $\mathbf{2}$ & $94.8(50)^{b}$ & $37.6(30)^{c}$ \\
$\mathbf{4} \mathbf{4}$ & $94.0(50)^{b}$ & n.t. \\
$\mathbf{4}$ & $73.1(50)^{b}$ & n.t. \\
$\mathbf{4 n}$ & $99.4(50)^{b}$ & n.t. \\
CLT $(\mathbf{1})$ & $6.0(50)^{b}$ & $28.3(150)^{b}$ \\
CQ & $100(10)^{b}$ & $89.1(10)^{b}$ \\
\hline
\end{tabular}

${ }^{a}$ Percent suppression $=[(C-T) / C] \times 100$; where $C=$ parasitaemia in control group and $T=$ parasitaemia in treated group after oral/i.p. administration. Five mice per group were used ${ }^{b}$ Oral administration. ${ }^{c}$ Intraperitoneal administration. ${ }^{d}$ n.t. $=$ not tested.

docking studies into 14-LD homology model ${ }^{26}$ of C. albicans. At this purpose, it has to be underlined that the unfavorable electronic and steric interactions with the residues present in the active site of 14-LD may not be the only determinant for substrate selectivity, as the external surface and the access channel properties may play a key role. ${ }^{27}$ Indeed we considered the presence of positively charged residues on the external surface of the active site and in the putative substrate access channel of 14-LD. Most of the positively charged residues identified in $C$. albicans 14-LD, including the K108 at the active site, are conserved in the other fungi P450 orthologs as well as in the active site of CYP3A4, the most important enzyme for drug metabolism in humans, where two arginine residues are placed in the same region occupied by K108. Our studies led to the hypothesis that the introduction of a protonatable group could decrease interaction with heme as $\mathrm{P} 450$ s prosthetic group.

These results were confirmed by determination of the antifungal activity of compounds $\mathbf{2}, \mathbf{4 e}$, and $\mathbf{4 n}$ against a panel of fungal species (Aspergillus spp., Candida spp., and one isolate of Cryptococcus neoformans). As shown in the SI, Table 1, none of the new compounds had any significant activity against these fungi, confirming the selectivity for free heme as the key factor for antimalarial activity of these innovative antimalarial agents.

4. Cytotoxicity: MTT Assays. Cytotoxicity for compounds $\mathbf{2}$ and $\mathbf{4 b}, \mathbf{b}, \mathbf{e}, \mathbf{g}$ was evaluated using plasmocytoma murine cell line (NSO cells), normal human lymphocytes PHA-stimulated, and human lymphoblastoid cell line (Daudi cells). Data are shown in Table 5 and were obtained by the 3-(4,5-dimethylthiazol-2-yl)-2,5-diphenyltetrazolium bromide (MTT) test aimed to analyze cell proliferation in cells cultured in the presence of different compounds. ${ }^{28}$ The data processing included the Student's $t$-test with $p<0.05$ taken as significance level. Cytotoxicity of compounds $\mathbf{4 d}, \mathbf{i}, \mathbf{l}-\mathbf{n}, \mathbf{p}$ was assessed by using KB cells, a cell line derived from a human carcinoma of the nasopharynx. All compounds tested showed low cytotoxicity in the MTT tests, thus demonstrating a good therapeutic index $(>300)$.

5. In Vivo Antimalarial Activity. Compound 2 and CLT were tested in female CD1, 20-25 g mice infected with $P$. berghei ANKA, while compounds $\mathbf{4} \mathbf{e}-\mathbf{g}, \mathbf{n}$, together with $\mathbf{2}$ and CLT, were tested in mice infected with $P$. chabaudi AS. For both murine strains of Plasmodium, in vivo antimalarial activity evaluation was performed according to the four-day suppressive test of Peters et al. ${ }^{29}$ Compounds were orally or intraperitoneally administered once daily for 4 days, with the first drug administered $2 \mathrm{~h}$ after i.v. parasite inoculation. Parasitaemia in untreated control mice generally reached $40 \%$ for $P$. chabaudi and $10 \%$ for $P$. berghei.

As displayed in Table 6, at an oral dose of $150 \mathrm{mg} / \mathrm{kg}$, CLT only caused a $28 \%$ suppression of parasitaemia against $P$. berghei, and, to our surprise, one of the most active compounds in vitro against CQ-S strains, namely, 2, was inactive at an oral dose of $30 \mathrm{mg} / \mathrm{kg}$ (data not shown) and only poorly active (37\%) after i.p. administration, while the control drug CQ was able to suppress parasitaemia by $89 \%$ at a dose of $10 \mathrm{mg} / \mathrm{kg}$. However, we found that $\mathbf{2}$, but not CLT, was active in vivo against $P$. chabaudi with parasitaemia suppression of $94.8 \%$ after oral administration at a dose of $50 \mathrm{mg} / \mathrm{kg}$. These rodent species notably differ in their ability to invade mature or immature erythrocytes and in their degrees of synchronism. At the moment, we have no explanation for the different activity of 2 against these strains, and further studies are in progress to address this question. However, it is of note that, in vitro, compound $\mathbf{2}$ and its analogues generally display higher $\mathrm{IC}_{50}$ values against synchronous 3D7 and K1 strains than asynchronous D10 and W2 strains. Consequently, P. chabaudi was used for the further in vivo evaluation of $\mathbf{2}$ analogues, and both $\mathbf{4 e}$ and $\mathbf{4 n}$ demonstrated high antimalarial activity in vivo. Doses of $50 \mathrm{mg} / \mathrm{kg}$ achieved 94.0 and $99.4 \%$ of parasitaemia suppression, respectively. On the other hand, at the same dose, compound $\mathbf{4 g}$ showed $\mathbf{7 3 . 1 \%}$ parasitaemia suppression, complementing its lower in vitro antimalarial activity with respect to $4 \mathrm{e}$ and $4 \mathrm{n}$.

\section{Conclusions}

This work led to the discovery of potent antimalarial agents structurally unrelated to known antiplasmodial drugs currently used in therapy or under development. The design strategy was focused on the development of polyaromatic compounds with high antimalarial activity especially against CQ-R strains and with high selectivity for free heme over P450 cytochrome prosthetic groups. The in vitro and in vivo antimalarial activity of this innovative class of antimalarials is dependent upon several key structural features: (i) the protonatable lateral chain, responsible for improved pharmacokinetic properties with respect to CLT, for selectivity for free heme over P450 cytochrome heme and for higher FV accumulation; (ii) the imidazole ring, with its dual role of heme-complexing group and substrate for the redox reaction generating the trityl radical; and (iii) the aryl/heteroaryl systems whose structural and electronic properties are key factors to influence the stabilization of a trityl radical intermediate.

Exploiting this novel pharmacophore potent antimalarials were identified, characterized by low in vitro toxicity against 
different human and murine cell lines and with no activity against fungal pathogens.

The most promising antimalarial compounds $\mathbf{2}, \mathbf{4 e}$, and $\mathbf{4 n}$ were further evaluated to assess their efficacy in vivo and resulted in activity against $P$. chabaudi in CD1 mice after oral administration in the four-day suppressive test. The development of these compounds is characterized by a limited number of synthetic steps and by low cost of goods. The straightforward synthetic pathway was further simplified with compound $\mathbf{4 e}$, where the chiral center was removed thus avoiding racemate resolution and improving drugability.

In summary, both antimalarials $\mathbf{2}$ and $\mathbf{4 e}$, which combine low propensity to generate rapid resistance, potent in vitro and in vivo activity against various plasmodia, and endowed with oral bioavailability, prove to be promising candidates for early preclinical development. These novel compounds meet the requirements necessary for their potential development as antimalarials in poverty-stricken regions where oral bioavailability, stability of the formulation, and affordability are strict selection criteria beside activity against drug-resistant strains and rapid mode of action.

\section{Experimental Section}

Chemistry. Reagents were purchased from Aldrich and were used as received. Reaction progress was monitored by TLC using Merck silica gel $60 \mathrm{~F}_{254}(0.040-0.063 \mathrm{~mm})$ with detection by UV. Merck silica gel $60(0.040-0.063 \mathrm{~mm})$ was used for column chromatography. Melting points were determined in Pyrex capillary tubes using an Electrothermal 8103 apparatus and are uncorrected. ${ }^{1} \mathrm{H}$ NMR and ${ }^{13} \mathrm{C}$ NMR spectra were recorded on Bruker $200 \mathrm{MHz}$, Varian $300 \mathrm{MHz}$, or Bruker $400 \mathrm{MHz}$ spectrometer with TMS as internal standard. Splitting patterns are described as singlet (s), doublet (d), triplet (t), quartet (q), and broad (br); the value of chemical shifts $(\delta)$ are given in ppm and coupling constants $(J)$ in Hertz (Hz). ESI-MS spectra were performed by an Agilent 1100 Series LC/MSD spectrometer. Elemental analyses were performed in a Perkin-Elmer $240 \mathrm{C}$ elemental analyzer and the results were within $\pm 0.4 \%$ of the theoretical values, unless otherwise noted. Yields refer to purified products and are not optimized. All moisturesensitive reactions were performed under argon atmosphere using oven-dried glassware and anhydrous solvents. All the organic layers were dried using anhydrous sodium sulfate.

( \pm )-(3-Chlorophenyl) [4-( $N, N$-diethylaminomethyl $)$ phenyl]methanol (7a). To a stirred suspension of magnesium turnings (122 $\mathrm{mg}, 5.0 \mathrm{mmol}$ ) in anhydrous tetrahydrofurane (THF; $8.0 \mathrm{~mL})$, a solution containing $N$-(4-bromobenzyl)- $N$-ethylethanamine $6^{30}(1.32$ $\mathrm{g}, 5.0 \mathrm{mmol})$ in dry THF $(8.0 \mathrm{~mL})$ was slowly added. The reaction mixture was stirred and heated under reflux until all magnesium was consumed $(1-2 \mathrm{~h})$. Thereafter, the reaction was cooled to 0 ${ }^{\circ} \mathrm{C}$ and a solution of 3-chlorobenzaldehyde 5 (506 mg, $3.6 \mathrm{mmol}$ ) in $10 \mathrm{~mL}$ of anhydrous THF was added during $2 \mathrm{~h}$, maintaining the temperature between -5 and $0{ }^{\circ} \mathrm{C}$. The reaction mixture was quenched by the dropwise addition of $20 \%$ ammonium chloride solution $(30 \mathrm{~mL})$. The layers were separated and the aqueous layer was extracted with EtOAc. The organic layer was washed with $10 \%$ $\mathrm{Na}_{2} \mathrm{CO}_{3}$ solution and dried over Drierite. Evaporation of the solvent afforded a residue, which was purified by flash chromatography (2\% $\mathrm{MeOH}$ in DCM) to give 7a as a light yellow oil $(1.0 \mathrm{~g}, 92 \%)$ : ${ }^{1} \mathrm{H}$ NMR $\left(200 \mathrm{MHz}, \mathrm{CDCl}_{3}\right) \delta 7.38-7.21(\mathrm{~m}, 8 \mathrm{H}), 5.67(\mathrm{~s}, 1 \mathrm{H})$, $3.79(\mathrm{bs}, 1 \mathrm{H}), 3.52$ (s, 2H), 2.47 (q, $4 \mathrm{H}, J=7.1 \mathrm{~Hz}), 1.01(\mathrm{t}, 6 \mathrm{H}$, $J=7.1 \mathrm{~Hz})$; ESI MS $\mathrm{m} / \mathrm{z}(\mathrm{M}+\mathrm{H})^{+} 304$.

$( \pm)$-(3-Chlorophenyl)\{4-[(N-tert-butoxycarbonylpiperazin-4yl)methyl]phenyl\}methanone (9). To a stirred solution of $\mathbf{8}^{6}(1.21$ $\mathrm{g}, 3.9 \mathrm{mmol})$ in dry $\mathrm{MeCN}(15 \mathrm{~mL})$ at $0{ }^{\circ} \mathrm{C}$ was added a solution of $N$-Boc-piperazine $(0.860 \mathrm{~g}, 4.6 \mathrm{mmol})$ and $\mathrm{Et}_{3} \mathrm{~N}(0.64 \mathrm{~mL}, 4.6$ $\mathrm{mmol})$ in $\mathrm{MeCN}(5 \mathrm{~mL})$, and the reaction mixture was allowed to stir for $2 \mathrm{~h}$. Thereafter, the reaction was quenched with $\mathrm{H}_{2} \mathrm{O}$ and the solvent was evaporated under reduced pressure. The residue was treated with water and extracted with $\mathrm{CHCl}_{3}$. The combined organic layers were washed with brine, dried over $\mathrm{Na}_{2} \mathrm{SO}_{4}$, and evaporated. The residue was chromatographed (1\% MeOH in DCM) to afford 9 as a yellow oil $(1.2 \mathrm{~g}, 74 \%)$ : ${ }^{1} \mathrm{H}$ NMR $(200 \mathrm{MHz}$, $\left.\mathrm{CDCl}_{3}\right) \delta 7.75-7.71(\mathrm{~m}, 3 \mathrm{H}), 7.65-7.61(\mathrm{~m}, 1 \mathrm{H}), 7.55-7.51(\mathrm{~m}$, $1 \mathrm{H}), 7.46-7.39(\mathrm{~m}, 3 \mathrm{H}), 3.56(\mathrm{~s}, 2 \mathrm{H}), 3.43(\mathrm{t}, 4 \mathrm{H}, J=5.0 \mathrm{~Hz})$, $2.39(\mathrm{t}, 4 \mathrm{H}, J=4.9 \mathrm{~Hz}), 1.43(\mathrm{~s}, 9 \mathrm{H})$; ESI MS $m / z(\mathrm{M}+\mathrm{H})^{+} 415$.

$( \pm)$-(3-Chlorophenyl) $\{4$-[( $N$-tert-butoxycarbonylpiperazin-4yl)methyl]phenyl\}methanol (7b). To a solution of $\mathbf{9}(0.746 \mathrm{~g}, 1.8$ $\mathrm{mmol}$ ) in ethanol (5 mL), sodium borohydride (140 mg, $3.7 \mathrm{mmol}$ ) was added portionwise at $0{ }^{\circ} \mathrm{C}$. The resulting mixture was stirred at $\mathrm{rt}$ for $30 \mathrm{~min}$ and then treated with $\mathrm{H}_{2} \mathrm{O}$ and concentrated under reduced pressure. The residue was extracted with EtOAc, and the combined organic layers were washed with brine, dried over $\mathrm{Na}_{2} \mathrm{SO}_{4}$, and evaporated. The residue was chromatographed (2\% $\mathrm{MeOH}$ in DCM) to afford $\mathbf{7 b}$ as a yellow oil $(540 \mathrm{mg}, 72 \%):{ }^{1} \mathrm{H}$ NMR (200 MHz, $\left.\mathrm{CDCl}_{3}\right) \delta$ 7.38-7.36 (m, 2H), 7.27-7.22 (m, 6H), $5.76(\mathrm{~s}, 1 \mathrm{H}), 3.46(\mathrm{~s}, 2 \mathrm{H}), 3.39(\mathrm{t}, 4 \mathrm{H}, J=4.9 \mathrm{~Hz}), 2.34(\mathrm{t}, 4 \mathrm{H}, J$ $=5.0 \mathrm{~Hz}), 1.44(\mathrm{bs}, 1 \mathrm{H}), 1.42(\mathrm{~s}, 9 \mathrm{H})$; ESI MS m/z $(\mathrm{M}+\mathrm{H})^{+}$ 417.

7-Chloroquinoline-4-carbaldehyde (11b). A solid mixture of 4,7-dichloroquinoline $\mathbf{1 0}(2.97 \mathrm{~g}, 15.1 \mathrm{mmol})$ and [1,2-bis(diphenylphosphino)ethane]-dichloronikel(II) $(60.0 \mathrm{mg}, 0.114 \mathrm{mmol})$ was evacuated and flushed with argon several times. Dry diethylether $(40 \mathrm{~mL})$ was then added and the solution was stirred at $0{ }^{\circ} \mathrm{C}$. Thereafter, a 3.0 M solution of methylmagnesium bromide in diethylether $(5.0 \mathrm{~mL}, 15.1 \mathrm{mmol})$ was added dropwise. The reaction mixture was allowed to warm at rt and stirred for $24 \mathrm{~h}$; thereafter, it was poured into saturated $\mathrm{NH}_{4} \mathrm{Cl}$ solution, and the ether layer was separated, dried over $\mathrm{Na}_{2} \mathrm{SO}_{4}$, and evaporated under reduced pressure to afford a crude solid that was purified by flash chromatography (15\% EtOAc in Hex) to afford 4-methyl-7chloroquinoline as a white solid $(1.5 \mathrm{~g}, 56 \%)$ : $\mathrm{mp} 59-61{ }^{\circ} \mathrm{C}$ (lit. $\left.\mathrm{mp} 57-58^{\circ} \mathrm{C}\right) .{ }^{16} \mathrm{~A}$ stirred mixture of the above compound $(1.17$ $\mathrm{g}, 6.6 \mathrm{mmol})$ and selenium dioxide $(1.17 \mathrm{~g}, 10.6 \mathrm{mmol})$ in bromobenzene $(16 \mathrm{~mL})$ was heated to $170{ }^{\circ} \mathrm{C}$ for $18 \mathrm{~h}$. The selenium was filtered off and washed with DCM and the filtrate was evaporated to dryness. The residue was taken up in DCM, filtered through celite, and evaporated to dryness, affording $\mathbf{1 1 b}$ as a colorless crystalline solid (740 mg, 57\%): $\mathrm{mp}(\mathrm{EtOH}) 108-110^{\circ} \mathrm{C}$ (lit. mp $\left.107-108{ }^{\circ} \mathrm{C}\right) .^{31}$

( \pm )-(3-Chlorophenylphenyl)(quinolin-4-yl)methanol (13). A solution of 11a $(0.487 \mathrm{~g}, 3.1 \mathrm{mmol})$ in dry THF $(25 \mathrm{~mL})$ was added dropwise to a solution of 3-chlorophenylmagnesium bromide $(0.5$ $\mathrm{M}$ in THF, $3.1 \mathrm{mmol}, 6.2 \mathrm{~mL}$ ), and the resulting solution was heated to $75{ }^{\circ} \mathrm{C}$ for $6 \mathrm{~h}$. The reaction mixture was quenched with $20 \%$ ammonium chloride solution. The aqueous layer was extracted with EtOAc, and the combined organic layers were washed with brine, dried over $\mathrm{Na}_{2} \mathrm{SO}_{4}$, and evaporated under reduced pressure. The crude residue was purified by flash chromatography $(2 \% \mathrm{MeOH}$ in $\left.\mathrm{CHCl}_{3}\right)$ to give $\mathbf{1 3}$ as a colorless oil $(0.40 \mathrm{~g}, 48 \%):{ }^{1} \mathrm{H} \mathrm{NMR}$ $\left(200 \mathrm{MHz}, \mathrm{CDCl}_{3}\right) \delta 8.77(\mathrm{~d}, 1 \mathrm{H}, J=8.0 \mathrm{~Hz}), 8.10(\mathrm{~d}, 1 \mathrm{H}, J=$ $6.0 \mathrm{~Hz}), 7.92(\mathrm{~d}, 1 \mathrm{H}, J=8.1 \mathrm{~Hz}), 7.68-7.45(\mathrm{~m}, 3 \mathrm{H}), 7.40-7.12$ $(\mathrm{m}, 4 \mathrm{H}), 6.39$ (s, 1H), $3.55(\mathrm{bs}, 1 \mathrm{H})$; ESI MS m/z $(\mathrm{M}+\mathrm{H})^{+} 270$.

( \pm )-[4-(Pyrrolidin-1-ylmethyl) phenyl] (quinolin-4-yl)methanol (14a). To a stirred solution of $12(0.624 \mathrm{~g}, 2.6 \mathrm{mmol})$ in dry THF $(15 \mathrm{~mL})$ was added dropwise $n$-butyllithium (1.6 M in Hex, $1.8 \mathrm{~mL}, 2.9 \mathrm{mmol})$ at $-78^{\circ} \mathrm{C}$ and was further stirred at $-60{ }^{\circ} \mathrm{C}$ for $3 \mathrm{~h}$. Thereafter, a solution of 4-quinolinecarbaldehyde $(0.456$ $\mathrm{g}, 2.9 \mathrm{mmol}$ ) in dry THF was added dropwise, and the temperature was maintained at $-60{ }^{\circ} \mathrm{C}$ for $2 \mathrm{~h}$. Subsequently, the reaction mixture was allowed to cool to rt, stirred for $24 \mathrm{~h}$, and finally quenched with a saturated solution of $\mathrm{NH}_{4} \mathrm{Cl}$. The aqueous layer was extracted with EtOAc and the combined organic layers were washed with brine, dried over $\mathrm{Na}_{2} \mathrm{SO}_{4}$, and evaporated under reduced pressure. The crude residue was purified by flash chromatography $(6 \% \mathrm{MeOH}$ in DCM) to afford 14a as a brown oil $(0.27 \mathrm{~g}, 32 \%):{ }^{1} \mathrm{H}$ NMR $\left(200 \mathrm{MHz}, \mathrm{CDCl}_{3}\right) \delta 8.80(\mathrm{~d}, 1 \mathrm{H}, J=4.2$ $\mathrm{Hz}), 8.06(\mathrm{~d}, 1 \mathrm{H}, J=8.2 \mathrm{~Hz}), 7.90(\mathrm{~d}, 1 \mathrm{H}, J=8.2 \mathrm{~Hz}), 7.68-7.60$ (m, 2H), 7.56-7.29 (m, 1H), 7.24-7.20 (m, 4H), 6.41 (s, 1H), 3.71 
(bs, 1H), $3.52(\mathrm{~s}, 2 \mathrm{H}), 2.42(\mathrm{~m}, 4 \mathrm{H}), 1.71(\mathrm{~m}, 4 \mathrm{H})$; ESI MS m/z $(\mathrm{M}+\mathrm{H})^{+} 319$.

( \pm )-[4-(Pyrrolidin-1-ylmethyl)phenyl](7-chloroquinolin-4-yl)methanol (14b). Starting from $11 b(170 \mathrm{mg}, 0.89 \mathrm{mmol})$, the title compound was prepared following the above-described procedure and was obtained as a brown oil $(62.0 \mathrm{mg}, 20 \%)$ : ${ }^{1} \mathrm{H}$ NMR (200 $\left.\mathrm{MHz}, \mathrm{CDCl}_{3}\right) \delta 8.87(\mathrm{~d}, 1 \mathrm{H}, J=4.5 \mathrm{~Hz}), 8.06(\mathrm{~d}, 1 \mathrm{H}, J=1.9$ $\mathrm{Hz}), 7.83(\mathrm{~d}, 1 \mathrm{H}, J=9.0 \mathrm{~Hz}), 7.67(\mathrm{~d}, 1 \mathrm{H}, J=4.3 \mathrm{~Hz}), 7.38-7.25$ (m, 5H), $6.36(\mathrm{~s}, 1 \mathrm{H}), 3.68$ (bs, 1H), $3.54(\mathrm{~s}, 2 \mathrm{H}), 2.45(\mathrm{~m}, 4 \mathrm{H})$, $1.73(\mathrm{~m}, 4 \mathrm{H})$; ESI MS $m / z(\mathrm{M}+\mathrm{H})^{+} 353$.

( \pm )-1-\{(3-Chlorophenyl)[4-( $N, N$-diethylaminomethyl)phenyl]methyl\}-1H-imidazole (3a). To a solution of 7a (75.9 mg, 0.25 $\mathrm{mmol})$ and a drop of DMF in dry DCM $(10 \mathrm{~mL})$ was added $\mathrm{SOCl}_{2}$ $(63.5 \mu \mathrm{L}, 0.87 \mathrm{mmol})$ in dry $\mathrm{DCM}(2 \mathrm{~mL})$ at $0{ }^{\circ} \mathrm{C}$, and the mixture was stirred at the same temperature for $20 \mathrm{~min}$ and thereafter at room temperature for $3.5 \mathrm{~h}$. The volatiles were removed, and the residue was washed with dry $\mathrm{MeCN}$ and concentrated under reduced pressure to remove residual $\mathrm{SOCl}_{2}$. The resulting hydrochloride salt ( $89.7 \mathrm{mg}, 0.25 \mathrm{mmol}$ ) was suspended in dry $\mathrm{MeCN}(5 \mathrm{~mL})$ and to this suspension was slowly added a solution containing $\mathrm{Et}_{3} \mathrm{~N}(70.0$ $\mu \mathrm{L}, 0.50 \mathrm{mmol})$ and imidazole $(34.1 \mathrm{mg}, 0.50 \mathrm{mmol})$ in $\mathrm{MeCN}(5$ $\mathrm{mL}$ ) at $0{ }^{\circ} \mathrm{C}$. Thereafter, the reaction mixture was heated to $80^{\circ} \mathrm{C}$ for $4 \mathrm{~h}$. The solvent was evaporated under reduced pressure, and the residue was treated with $\mathrm{H}_{2} \mathrm{O}$ and extracted with EtOAc. The combined organic layers were dried over $\mathrm{Na}_{2} \mathrm{SO}_{4}$ and concentrated in vacuo. The crude product was purified by flash column chromatography (1\% $\mathrm{MeOH}$ in DCM) to afford $\mathbf{3 a}$ as a brown oil (60.2 mg, 68\%): ${ }^{1} \mathrm{H}$ NMR (200 MHz, $\left.\mathrm{CDCl}_{3}\right) \delta 7.39-7.27(\mathrm{~m}, 5 \mathrm{H})$, 7.09-6.94 (m, 3H), $6.82(\mathrm{~s}, 3 \mathrm{H}), 6.45(\mathrm{~s}, 1 \mathrm{H}), 3.56(\mathrm{~s}, 2 \mathrm{H}), 2.52$ $(\mathrm{q}, 4 \mathrm{H}, J=7.0 \mathrm{~Hz}), 1.03(\mathrm{t}, 6 \mathrm{H}, J=7.0 \mathrm{~Hz}) ; \mathrm{MS} \mathrm{m} / \mathrm{z}(\mathrm{M}+\mathrm{H})^{+}$ 354. Anal. $\left(\mathrm{C}_{21} \mathrm{H}_{24} \mathrm{ClN}_{3}\right) \mathrm{C}, \mathrm{H}, \mathrm{N}$.

( \pm -1-\{(3-Chlorophenyl)[4-( $N, N$-diethylaminomethyl)phenyl]methyl\}-1H-1,2,4-triazole (3b). Starting from 7a (66.8 mg, 0.22 $\mathrm{mmol}$ ), the title compound was prepared following the abovedescribed procedure and was obtained as brown oil (52.0 mg, 68\%): ${ }^{1} \mathrm{H}$ NMR $\left(200 \mathrm{MHz}, \mathrm{CDCl}_{3}\right) \delta 8.01(\mathrm{~s}, 1 \mathrm{H}), 7.86(\mathrm{~s}, 1 \mathrm{H}), 7.39-7.28$ (m, 5H), 7.08-7.01 (m, 3H), 6.93-6.89 (m, 1H), $3.56(\mathrm{~s}, 2 \mathrm{H}), 2.51$ $(\mathrm{q}, 4 \mathrm{H}, J=7 \mathrm{~Hz}), 1.03(\mathrm{t}, 6 \mathrm{H}, J=6.9 \mathrm{~Hz})$; ESI MS $\mathrm{m} / \mathrm{z}(\mathrm{M}+$ $\mathrm{H})^{+}$355. Anal. $\left(\mathrm{C}_{20} \mathrm{H}_{23} \mathrm{ClN}_{4}\right) \mathrm{C}, \mathrm{H}, \mathrm{N}$.

( \pm -1-\{(3-Chlorophenyl) [4-[(N-tert-butoxycarbonylpiperazin4-yl)methyl]phenyl]methyl\}-1H-imidazole (3c). Starting from $7 \mathbf{b}$ $(0.54 \mathrm{~g}, 1.3 \mathrm{mmol})$, the title compound was prepared following the above-described procedure and was obtained as brown oil $(0.37 \mathrm{~g}$, 61\%): ${ }^{1} \mathrm{H}$ NMR $\left(200 \mathrm{MHz}, \mathrm{CDCl}_{3}\right) \delta 7.42(\mathrm{~s}, 1 \mathrm{H}), 7.37-7.21(\mathrm{~m}$, $4 \mathrm{H}), 7.04-6.93(\mathrm{~m}, 5 \mathrm{H}), 6.80(\mathrm{~s}, 1 \mathrm{H}), 6.43(\mathrm{~s}, 1 \mathrm{H}), 3.47(\mathrm{~s}, 2 \mathrm{H})$, $3.39(\mathrm{t}, 4 \mathrm{H}, J=4.7 \mathrm{~Hz}), 2.35(\mathrm{t}, 4 \mathrm{H}, J=4.7 \mathrm{~Hz}), 1.42(\mathrm{~s}, 9 \mathrm{H})$; ESI MS $m / z(\mathrm{M}+\mathrm{H})^{+}$467. Anal. $\left(\mathrm{C}_{26} \mathrm{H}_{31} \mathrm{ClN}_{4} \mathrm{O}_{2}\right) \mathrm{C}, \mathrm{H}, \mathrm{N}$.

( \pm )-1-\{(3-Chlorophenyl)[4-[(piperazin-1-yl)methyl]phenyl]methyl $\}-1 H$-imidazole (3d). A solution of $\mathbf{3 c}(98.1 \mathrm{mg}, 0.21 \mathrm{mmol})$ in a 1:1 TFA/DCM mixture $(3.5 \mathrm{~mL})$ was stirred at $0-5^{\circ} \mathrm{C}$ for $3 \mathrm{~h}$. Then the solvent was evaporated and the residue was treated with $2.5 \mathrm{M} \mathrm{NaOH}$. The aqueous phase was extracted with DCM, and the organic layer was dried over $\mathrm{Na}_{2} \mathrm{SO}_{4}$ and concentrated in vacuo. The crude residue was purified by flash column chromatography $\left(8 \% \mathrm{MeOH}_{\text {in }} \mathrm{CHCl}_{3}\right)$ to afford $\mathbf{3 d}$ as a yellow oil $(67.0 \mathrm{mg}, 87 \%)$ : ${ }^{1} \mathrm{H}$ NMR $\left(200 \mathrm{MHz}, \mathrm{CDCl}_{3}\right) \delta 7.37(\mathrm{~s}, 1 \mathrm{H}), 7.32-7.22(\mathrm{~m}, 4 \mathrm{H})$, 7.08-6.91 (m, 5H), $6.81(\mathrm{~s}, 1 \mathrm{H}), 6.43(\mathrm{~s}, 1 \mathrm{H}), 3.47(\mathrm{~s}, 2 \mathrm{H}), 2.87(\mathrm{t}$, $4 \mathrm{H}, J=4.7 \mathrm{~Hz}), 2.39$ (t, 4H, $J=4.3 \mathrm{~Hz}$ ); 2.22 (bs, 1H); ESI MS $\mathrm{m} / \mathrm{z}(\mathrm{M}+\mathrm{H})^{+}$367. Anal. $\left(\mathrm{C}_{21} \mathrm{H}_{23} \mathrm{ClN}_{4}\right) \mathrm{C}, \mathrm{H}, \mathrm{N}$.

( \pm )-4-[(1H-Imidazol-1-yl)(3-chlorophenyl)methyl]quinoline (3e). Starting from $\mathbf{1 3}(0.38 \mathrm{~g}, 1.4 \mathrm{mmol})$, the title compound was prepared following the above-described procedure and was obtained as pale yellow oil $(0.29 \mathrm{~g}, 65 \%):{ }^{1} \mathrm{H}$ NMR $\left(200 \mathrm{MHz}, \mathrm{CDCl}_{3}\right) \delta$ $8.88(\mathrm{~d}, 1 \mathrm{H}, J=8.0 \mathrm{~Hz}), 8.14(\mathrm{~d}, 1 \mathrm{H}, J=6.0 \mathrm{~Hz}), 7.94(\mathrm{~d}, 1 \mathrm{H}$, $J=8.1 \mathrm{~Hz}), 7.68-7.45(\mathrm{~m}, 3 \mathrm{H}), 7.43-7.10(\mathrm{~m}, 6 \mathrm{H}), 6.89(\mathrm{~s}, 1 \mathrm{H})$, $6.74(\mathrm{~d}, 1 \mathrm{H}, J=4.4 \mathrm{~Hz})$; ESI MS $m / z(\mathrm{M}+\mathrm{H})^{+}$320. Anal. $\left(\mathrm{C}_{19} \mathrm{H}_{14} \mathrm{ClN}_{3}\right) \mathrm{C}, \mathrm{H}, \mathrm{N}$.

( \pm )-4-\{(1H-Imidazol-1-yl)[4-(pyrrolidin-1-ylmethyl)phenyl]methyl quinoline (3f). To a solution of $14 a(0.382 \mathrm{~g}, 1.2 \mathrm{mmol})$ and a drop of DMF in dry DCM $(5 \mathrm{~mL})$ was added $\mathrm{SOCl}_{2}(263$ $\mu \mathrm{L}, 3.6 \mathrm{mmol})$ in dry $\mathrm{DCM}(5 \mathrm{~mL})$ at $0{ }^{\circ} \mathrm{C}$, and the mixture was stirred at $0{ }^{\circ} \mathrm{C}$ for $20 \mathrm{~min}$ and thereafter at rt for $5 \mathrm{~h}$. After evaporation of the solvent, the residue was dissolved in EtOAc and the organic layer was washed with saturated $\mathrm{NaHCO}_{3}, \mathrm{H}_{2} \mathrm{O}$, and brine and dried over $\mathrm{Na}_{2} \mathrm{SO}_{4}$. The crude product was purified by flash chromatography (2\% MeOH in DCM) to afford 4- - chloro[4(pyrrolidin-1-ylmethyl) phenyl]methyl $\}$ quinoline as a yellow oil (0.33 g, 78\%): ${ }^{1} \mathrm{H}$ NMR (200 MHz, $\left.\mathrm{CDCl}_{3}\right) \delta 8.92(\mathrm{~d}, 1 \mathrm{H}, J=4.3$ $\mathrm{Hz}), 8.13(\mathrm{~d}, 1 \mathrm{H}, J=7.8 \mathrm{~Hz}), 7.96(\mathrm{~d}, 1 \mathrm{H}, J=8.0 \mathrm{~Hz}), 7.70-7.58$ (m, 2H), 7.58-7.45 (m, 1H), 7.36-7.24 (m, 4H), 6.77 (s, 1H), 3.56 $(\mathrm{s}, 2 \mathrm{H}), 2.46(\mathrm{~m}, 4 \mathrm{H}), 1.73(\mathrm{~m}, 4 \mathrm{H})$; ESI MS $m / z(\mathrm{M}+\mathrm{H})^{+} 337$. To a stirred solution of the above compound $(250 \mathrm{mg}, 0.74 \mathrm{mmol})$ in dry DMF $(1 \mathrm{~mL})$ was added imidazole sodium salt $(136 \mathrm{mg}, 1.5$ $\mathrm{mmol})$, and the reaction mixture was heated to $80^{\circ} \mathrm{C}$ for $3 \mathrm{~h}$. The solvent was evaporated under reduced pressure and the residue was treated with $\mathrm{H}_{2} \mathrm{O}$ and extracted with EtOAc. The combined organic layers were washed with brine, dried over $\mathrm{Na}_{2} \mathrm{SO}_{4}$, and evaporated under reduced pressure. The crude residue was purified by flash chromatography ( $2 \% \mathrm{MeOH}$ in $\mathrm{DCM})$ to give $3 \mathbf{f}$ as a brown oil (140 mg, 52\%): ${ }^{1} \mathrm{H}$ NMR (200 MHz, $\left.\mathrm{CDCl}_{3}\right) \delta 8.84(\mathrm{~d}, 1 \mathrm{H}, J=$ $4.0 \mathrm{~Hz}), 8.14(\mathrm{~d}, 1 \mathrm{H}, J=8.2 \mathrm{~Hz}), 7.72-7.64(\mathrm{~m}, 2 \mathrm{H}), 7.48-7.30$ $(\mathrm{m}, 4 \mathrm{H}), 7.25-7.05(\mathrm{~m}, 4 \mathrm{H}), 6.81(\mathrm{~s}, 1 \mathrm{H}), 6.71(\mathrm{~d}, 1 \mathrm{H}, J=4.5$ $\mathrm{Hz}), 3.58(\mathrm{~s}, 2 \mathrm{H}), 2.47(\mathrm{~m}, 4 \mathrm{H}), 1.75(\mathrm{~m}, 4 \mathrm{H})$; ESI MS $\mathrm{m} / \mathrm{z}(\mathrm{M}+$ $\mathrm{H})^{+}$369. Anal. $\left(\mathrm{C}_{24} \mathrm{H}_{24} \mathrm{~N}_{4}\right) \mathrm{C}, \mathrm{H}, \mathrm{N}$.

( \pm )-7-Chloro-4-\{(1H-Imidazol-1-yl)[4-(pyrrolidin-1-ylmethyl)phenyl]methyl $\}$ quinoline (3g). Starting from 14b $(35.0 \mathrm{mg}$, $0.099 \mathrm{mmol}$ ), the title compound was prepared following the abovedescribed procedure and was obtained as a brown oil $(22.0 \mathrm{mg}$, 55\%): ${ }^{1} \mathrm{H}$ NMR $\left(200 \mathrm{MHz}, \mathrm{CDCl}_{3}\right) \delta 8.85(\mathrm{~d}, 1 \mathrm{H}, J=4.0 \mathrm{~Hz})$, $8.14(\mathrm{~s}, 1 \mathrm{H}), 7.64(\mathrm{~d}, 1 \mathrm{H}, J=9.0 \mathrm{~Hz}), 7.42-7.32(\mathrm{~m}, 4 \mathrm{H}), 7.25-7.04$ $(\mathrm{m}, 4 \mathrm{H}), 6.81(\mathrm{~s}, 1 \mathrm{H}), 6.69(\mathrm{~d}, 1 \mathrm{H}, J=4.3 \mathrm{~Hz}), 3.60(\mathrm{~s}, 2 \mathrm{H}), 2.49$ $(\mathrm{m}, 4 \mathrm{H}), 1.76(\mathrm{~m}, 4 \mathrm{H})$; ESI MS $\mathrm{m} / z(\mathrm{M}+\mathrm{H})^{+}$403. Anal. $\left(\mathrm{C}_{24} \mathrm{H}_{23} \mathrm{ClN}_{4}\right) \mathrm{C}, \mathrm{H}, \mathrm{N}$.

(4-Chlorophenyl)[4-(diethylaminomethyl) phenyl]methanone(16a). To a stirred solution of $\mathbf{1 5}(3.5 \mathrm{~g}, 11.3 \mathrm{mmol})$ in dry $\mathrm{MeCN}$ (75 mL), cooled to $0{ }^{\circ} \mathrm{C}$, diethylamine $(1.41 \mathrm{~mL}, 16.9 \mathrm{mmol})$ and triethylamine $(3.15 \mathrm{~mL}, 22.6 \mathrm{mmol})$ were added, and the resulting mixture was allowed to stir for $1 \mathrm{~h}$ at $0{ }^{\circ} \mathrm{C}$. Thereafter, the reaction was quenched with $\mathrm{H}_{2} \mathrm{O}$ and the solvent was evaporated under reduced pressure. The residue was treated with $\mathrm{H}_{2} \mathrm{O}$ and extracted with $\mathrm{CHCl}_{3}$. The combined organic layers were washed with brine, dried over $\mathrm{Na}_{2} \mathrm{SO}_{4}$, and evaporated. The residue was chromatographed (2\% MeOH in DCM) to afford 16a as a yellow oil (2.8 g, 82\%): ${ }^{1} \mathrm{H}$ NMR $\left(300 \mathrm{MHz}, \mathrm{CDCl}_{3}\right) \delta 7.74-7.70(\mathrm{~m}, 4 \mathrm{H}), 7.47-7.41$ $(\mathrm{m}, 4 \mathrm{H}), 3.62(\mathrm{~s}, 2 \mathrm{H}), 2.53(\mathrm{q}, 4 \mathrm{H}, J=7.0 \mathrm{~Hz}), 1.04(\mathrm{t}, 6 \mathrm{H}, J=$ $7.0 \mathrm{~Hz})$; ESI MS $m / z(\mathrm{M}+\mathrm{H})^{+} 302$.

(4-Chlorophenyl)\{4-[(morpholin-4-yl) methyl] phenyl\}methanone (16b). Starting from $15(3.00 \mathrm{~g}, 9.7 \mathrm{mmol})$ and morpholine (1.02 $\mathrm{mL}, 11.6 \mathrm{mmol})$, the title compound was prepared following the above-described procedure and was obtained as a white low melting amorphous solid $(2.5 \mathrm{~g}, 81 \%)$ : ${ }^{1} \mathrm{H}$ NMR $\left(300 \mathrm{MHz}, \mathrm{CDCl}_{3}\right)$ d 7.76-7.72 (m, 4H), 7.47-7.44 (m, 4H), 3.74-3.71 (m, 4H), 3.57 (s, 2H), 2.48-2.45 (m, 4H); ESI MS m/z $(\mathrm{M}+1)^{+} 316$.

(4-Chlorophenyl)\{4-[1-(tert-butoxycarbonyl)piperazin-4ylmethyl]phenyl\}methanone (16c). Starting from 15 (2.88 g, 9.3 $\mathrm{mmol})$ and $N$-Boc-piperazine $(2.08 \mathrm{~g}, 11.2 \mathrm{mmol})$, the title compound was prepared following the above-described procedure and was obtained as a white low melting amorphous solid (2.0 g, 51\%): ${ }^{1} \mathrm{H} \mathrm{NMR}\left(300 \mathrm{MHz}, \mathrm{CDCl}_{3}\right) \delta 7.73-7.69(\mathrm{~m}, 4 \mathrm{H}), 7.43-7.40$ (m, 4H), 3.55 (s, 2H), 3.43-3.40 (m, 4H), 2.40-2.37 (m, 4H), 1.42 $(\mathrm{s}, 9 \mathrm{H})$; ESI MS $m / z(\mathrm{M}+\mathrm{H})^{+} 415$.

$( \pm)$-(4-Chlorophenyl)[4-(diethylaminomethyl)phenyl]phenylmethanol (17a). The Grignard reagent was prepared in the usual manner as described for 7a from bromobenzene $(0.60 \mathrm{~mL}, 5.7$ $\mathrm{mmol})$, magnesium turnings (138 $\mathrm{mg}, 5.7 \mathrm{mmol})$, and a catalytic amount of iodine in dry THF $(35 \mathrm{~mL})$. A solution of 16a $(1.15 \mathrm{~g}$, $3.8 \mathrm{mmol})$ in dry THF $(25 \mathrm{~mL})$ was added dropwise to the Grignard reagent, and the resulting solution was heated to $75^{\circ} \mathrm{C}$ for $6 \mathrm{~h}$. The reaction mixture was quenched with $20 \%$ ammonium chloride solution. The aqueous layer was extracted with EtOAc, and the combined organic layers were washed with brine, dried over $\mathrm{Na}_{2} \mathrm{SO}_{4}$, and evaporated under reduced pressure. The crude residue 
was purified by flash chromatography $\left(2 \% \mathrm{MeOH}\right.$ in $\left.\mathrm{CHCl}_{3}\right)$ to give 16a as a yellow oil $(220 \mathrm{mg}, 45 \%)$ : ${ }^{1} \mathrm{H} \mathrm{NMR}(300 \mathrm{MHz}$, $\left.\mathrm{CDCl}_{3}\right) \delta 7.32-7.16(\mathrm{~m}, 13 \mathrm{H}), 3.59(\mathrm{~m}, 2 \mathrm{H}), 3.0(\mathrm{bs}, 1 \mathrm{H}), 2.55(\mathrm{q}$, $4 \mathrm{H}, J=7.0 \mathrm{~Hz}), 1.06(\mathrm{t}, 6 \mathrm{H}, J=7.0 \mathrm{~Hz})$; ESI MS $m / z(\mathrm{M}+\mathrm{H})^{+}$ 379.

( \pm )-(4-Chlorophenyl) \{4-[(morpholino-4-yl)methyl]phenyl\}phenylmethanol (17b). Starting from 16b $(0.347 \mathrm{~g}, 1.1 \mathrm{mmol})$, the title compound was prepared following the above-described procedure and was obtained as a yellow oil $(0.35 \mathrm{~g}, 81 \%):{ }^{1} \mathrm{H}$ NMR $\left(300 \mathrm{MHz}, \mathrm{CDCl}_{3}\right) \delta 7.29-7.18(\mathrm{~m}, 13 \mathrm{H}), 3.64-3.61(\mathrm{~m}, 4 \mathrm{H}), 3.46$ (s, 2H), 2.41-2.38 (m, 4H); ESI MS $m / z,(\mathrm{M}+\mathrm{H})^{+} 394$.

( \pm )-(4-Chlorophenyl)\{4-[1-(tert-butoxycarbonyl)piperazin-4ylmethyl]phenyl\}phenylmethanol (17c). Starting from 16c $(0.661$ $\mathrm{g}, 1.6 \mathrm{mmol}$ ), the title compound was prepared following the abovedescribed procedure and was obtained as a yellow oil $(0.40 \mathrm{~g}, 51 \%)$ : ${ }^{1} \mathrm{H}$ NMR $\left(300 \mathrm{MHz}, \mathrm{CDCl}_{3}\right) \delta 7.28-7.17(\mathrm{~m}, 13 \mathrm{H}), 3.47(\mathrm{~s}, 2 \mathrm{H})$, 3.40-3.37 (m, 4H), 2.37-2.34 (m, 4H), $1.44(\mathrm{~s}, 9 \mathrm{H})$; ESI MS m/z $(\mathrm{M}+\mathrm{H})^{+} 493$.

( \pm )-(4-Chlorophenyl)(4-fluorophenyl)[4-(pyrrolidin-1-ylmethyl)phenyl]methanol (18a). Starting from $\mathbf{1 6 d}^{6}(1.11 \mathrm{~g}, 3.7 \mathrm{mmol})$ and $p$-fluorobromobenzene, the title compound was prepared as described for 17a and was obtained as a brown oil $(0.94 \mathrm{~g}, 65 \%)$ : ${ }^{1} \mathrm{H}$ NMR $\left(300 \mathrm{MHz}, \mathrm{CDCl}_{3}\right) \delta$ 7.33-7.16 (m, 10H), 7.01-6.99 (m, $2 \mathrm{H}), 3.66$ (s, 2H), 2.78 (bs, 1H), $2.58(\mathrm{~m}, 4 \mathrm{H}), 1.83-1.82(\mathrm{~m}, 4 \mathrm{H})$; ESI MS $m / z,(\mathrm{M}+\mathrm{H})^{+} 396$.

(4-Chlorophenyl)bis[4-(pyrrolidin-1-ylmethyl)phenyl]methanol (18b). Starting from 16d ${ }^{6}(222 \mathrm{mg}, 0.74 \mathrm{mmol})$ and $12,{ }^{6}$ the title compound was prepared following the above-described procedure and was obtained as a brown oil (240 mg, 70\%): ${ }^{1} \mathrm{H}$ NMR $\left(300 \mathrm{MHz}, \mathrm{CDCl}_{3}\right) \delta 7.27-7.15(\mathrm{~m}, 12 \mathrm{H}), 3.59(\mathrm{~s}, 4 \mathrm{H}), 3.59$ (bs, $1 \mathrm{H}), 2.50-2.47(\mathrm{~m}, 8 \mathrm{H}), 1.78-1.76(\mathrm{~m}, 8 \mathrm{H})$; ESI MS $\mathrm{m} / \mathrm{z}(\mathrm{M}+$ $\mathrm{H})^{+} 461$.

(3-Chlorophenyl)(thien-2-yl)methanone (20a). To a stirred solution of 2-thiophenecarbaldehyde 19a $(2.38 \mathrm{~g}, 10.7 \mathrm{mmol})$ in dry THF $(10 \mathrm{~mL})$ was added dropwise 3-clorophenylmagnesiumbromide $(0.5 \mathrm{~N}$ solution in THF, $10.6 \mathrm{~mL}, 5.3 \mathrm{mmol})$, and the mixture was refluxed for $3 \mathrm{~h}$. After cooling to $\mathrm{rt}$, the reaction mixture was quenched by dropwise addition of a saturated solution of $\mathrm{NH}_{4} \mathrm{Cl}$. The aqueous phase was extracted with ethyl acetate and washed with brine. The combined organic layers were dried over $\mathrm{Na}_{2} \mathrm{SO}_{4}$ and evaporated. The crude residue was purified by flash chromatography (20\% EtOAc in Hex) to afford the title compound as colorless prisms $(0.99 \mathrm{~g}, 84 \%): \mathrm{mp}(n$-Hex $) 95-96{ }^{\circ} \mathrm{C} ;{ }^{1} \mathrm{H}$ NMR $\left(300 \mathrm{MHz}, \mathrm{CDCl}_{3}\right) \delta 7.82-7.80(\mathrm{~m}, 1 \mathrm{H}), 7.75-7.70(\mathrm{~m}, 2 \mathrm{H})$, $7.63-7.61(\mathrm{~m}, 1 \mathrm{H}), 7.56-7.52(\mathrm{~m}, 1 \mathrm{H}), 7.45-7.42(\mathrm{~m}, 1 \mathrm{H})$, $7.18-7.15(\mathrm{~m}, 1 \mathrm{H})$; ESI MS $m / z(\mathrm{M}+\mathrm{H})^{+} 223$.

(3-Chlorophenyl)(thiazol-2-yl)methanone (20b). Starting from 3-chlorophenylmagnesium bromide and 2-thiazolecarbaldehyde 19b (2.45 g, $22.1 \mathrm{mmol})$, the title compound was prepared following the above-described procedure and was obtained as colorless prisms (2.3 g, 93\%): mp (n-Hex) 87-88 ${ }^{\circ} \mathrm{C} ;{ }^{1} \mathrm{H} \mathrm{NMR}\left(300 \mathrm{MHz}, \mathrm{CDCl}_{3}\right)$ $\delta 8.41-8.39(\mathrm{~m}, 2 \mathrm{H}), 8.03(\mathrm{~d}, 1 \mathrm{H}, J=2.9 \mathrm{~Hz}), 7.66(\mathrm{~d}, 1 \mathrm{H}, J=$ $2.9 \mathrm{~Hz}), 7.47-7.44(\mathrm{~m}, 2 \mathrm{H})$; ESI MS $m / z(\mathrm{M}+\mathrm{H})^{+} 224$.

(3-Chlorophenyl)(furan-3-yl)methanone (20c). Starting from 3-chlorophenylmagnesium bromide and 3-furancarbaldehyde 19c (1.47 $\mathrm{g}, 15.3 \mathrm{mmol})$, the title compound was prepared following the above-described procedure and was obtained as colorless prisms $(0.70 \mathrm{~g}, 45 \%): \mathrm{mp}\left(n\right.$-Hex) $94-95{ }^{\circ} \mathrm{C} ;{ }^{1} \mathrm{H} \mathrm{NMR}\left(300 \mathrm{MHz}, \mathrm{CDCl}_{3}\right)$ $\delta 7.93(\mathrm{dd}, 1 \mathrm{H}, J=1.4,1.0 \mathrm{~Hz}), 7.83-7.81(\mathrm{~m}, 1 \mathrm{H}), 7.74-7.71$ $(\mathrm{m}, 1 \mathrm{H}), 7.58-7.54(\mathrm{~m}, 1 \mathrm{H}), 7.53-7.51(\mathrm{~m}, 1 \mathrm{H}), 7.46-7.40(\mathrm{~m}, 1 \mathrm{H})$, $6.89(\mathrm{dd}, 1 \mathrm{H}, J=1.7,1.0 \mathrm{~Hz})$; ESI MS $m / z(\mathrm{M}+\mathrm{H})^{+} 207$.

(3-Chlorophenyl)(pyridin-2-yl)methanone (20d). Starting from 3-chlorophenylmagnesium bromide and 2-pyridinecarboxaldehyde 19d $(1.00 \mathrm{~g}, 9.3 \mathrm{mmol})$, the title compound was prepared following the above-described procedure and was obtained as colorless prisms $(0.40 \mathrm{~g}, 40 \%): \mathrm{mp}(n-\mathrm{Hex}) 82-83{ }^{\circ} \mathrm{C} ;{ }^{1} \mathrm{H} \mathrm{NMR}\left(300 \mathrm{MHz}, \mathrm{CDCl}_{3}\right)$ d 8.81-8.78 (m, 2H), 7.74-7.72 (m, 1H), 7.60-6.98 (m, 1H), 7.59-7.52 (m, 1H), 7.56-7.52 (m, 2H), 7.45-7.38 (m, 1H); MS $m / z(\mathrm{M}+1)^{+} 218$; ESI MS $m / z(\mathrm{M}+\mathrm{H})^{+}$.

(3-Chlorophenyl)(pyridyl-4-yl)methanone (20e). Starting from 3-chlorophenylmagnesium bromide and 4-pyridinecarboxaldehyde 19e ( $1.0 \mathrm{~g}, 9.3 \mathrm{mmol})$, the title compound was prepared following the above-described procedure and was obtained as colorless prisms $(0.63 \mathrm{~g}, 64 \%)$ : mp (n-Hex) 99-100 ${ }^{\circ} \mathrm{C} ;{ }^{1} \mathrm{H}$ NMR $\left(300 \mathrm{MHz}, \mathrm{CDCl}_{3}\right)$ $\delta 8.82(\mathrm{~d}, 1 \mathrm{H}, J=1.7 \mathrm{~Hz}), 8.80(\mathrm{~d}, 1 \mathrm{H}, J=1.5 \mathrm{~Hz}), 7.79-7.77$ $(\mathrm{m}, 1 \mathrm{H}), 7.67-7.64(\mathrm{~m}, 1 \mathrm{H}), 7.62-7.58(\mathrm{~m}, 1 \mathrm{H}), 7.56-7.54(\mathrm{~m}, 2 \mathrm{H})$, $7.47-7.41(\mathrm{~m}, 1 \mathrm{H}) ; \mathrm{MS} \mathrm{m} / \mathrm{z}(\mathrm{M}+\mathrm{H})^{+} 218$.

(4-Chlorophenyl)(thien-2-yl)methanone (21a). Starting from 4-chlorophenylmagnesium bromide and 2-thiophenecarbaldehyde 19a $(1.98 \mathrm{~g}, 17.8 \mathrm{mmol})$, the title compound was prepared following the above-described procedure and was obtained as colorless prisms (1.6 g, 80\%): $\mathrm{mp}\left(n\right.$-Hex) $91-92{ }^{\circ} \mathrm{C} ;{ }^{1} \mathrm{H}$ NMR $\left(\mathrm{CDCl}_{3}\right) \delta 7.84-7.79$ $(\mathrm{m}, 2 \mathrm{H}), 7.74(\mathrm{dd}, 1 \mathrm{H}, J=1.1 \mathrm{~Hz}, 4.7 \mathrm{~Hz}), 7.62(\mathrm{dd}, 1 \mathrm{H}, J=1.1$ $\mathrm{Hz}, 3.8 \mathrm{~Hz}), 7.49-7.45(\mathrm{~m}, 2 \mathrm{H}), 7.16(\mathrm{dd}, 1 \mathrm{H}, J=3.8 \mathrm{~Hz}, 4.7$ $\mathrm{Hz})$; ESI MS $m / z(\mathrm{M}+1)^{+} 223$.

(4-Chlorophenyl)(thiazol-2-yl)methanone (21b). Starting from 4-chlorophenylmagnesium bromide and 2-thiazolecarbaldehyde 19b ( $2.50 \mathrm{~g}, 22.1 \mathrm{mmol})$, the title compound was prepared following the above-described procedure and was obtained as colorless prisms $(2.3 \mathrm{~g}, 91 \%): \mathrm{mp}(n-\mathrm{Hex}) 79-80{ }^{\circ} \mathrm{C} ;{ }^{1} \mathrm{H}$ NMR $\left(300 \mathrm{MHz}, \mathrm{CDCl}_{3}\right)$ $\delta 8.44-8.41(\mathrm{~m}, 2 \mathrm{H}), 7.98(\mathrm{~d}, 1 \mathrm{H}, J=2.7 \mathrm{~Hz}), 7.52(\mathrm{~d}, 1 \mathrm{H}, J=$ $3.0 \mathrm{~Hz}), 7.45-7.42(\mathrm{~m}, 2 \mathrm{H})$; ESI MS $\mathrm{m} / \mathrm{z}(\mathrm{M}+\mathrm{H})^{+} 224$.

( \pm )-(3-Chlorophenyl)[4-(pyrrolidin-1-ylmethyl)phenyl](thien2-yl)methanol (22a). Starting from 12, magnesium turnings, and 20a $(289 \mathrm{mg}, 1.30 \mathrm{mmol})$, the title compound was prepared as described for 17a and was obtained as colorless prisms (340 mg, 66\%): mp (EtOAc/n-Hex) 70-71 ${ }^{\circ} \mathrm{C} ;{ }^{1} \mathrm{H}$ NMR (300 $\mathrm{MHz}, \mathrm{CDCl}_{3}$ ) $\delta$ 7.43-7.42 (m, 1H), 7.38-7.22 (m, 8H), 6.96-6.93 (m, 1H), 6.72-6.71 (m, 1H), 3.73 (s, 2H), 3.10 (bs, 1H), 2.57-2.53 (m, 4H), $1.79-1.75(\mathrm{~m}, 4 \mathrm{H})$; ESI MS $m / z(\mathrm{M}+\mathrm{H})^{+} 384$.

( \pm )-(3-Chlorophenyl)[4-(pyrrolidin-1-ylmethyl)phenyl](thiazol2-yl)methanol (22b). Starting from 12, magnesium turnings, and $20 \mathrm{~b}(1.21 \mathrm{~g}, 5.4 \mathrm{mmol})$, the title compound was prepared following the above-described procedure and was obtained as colorless prisms (0.9 g, 46\%): mp (EtOAc/n-Hex) $73-74{ }^{\circ} \mathrm{C} ;{ }^{1} \mathrm{H}$ NMR $(200 \mathrm{MHz}$, $\left.\mathrm{CDCl}_{3}\right) \delta 7.81(\mathrm{~d}, 1 \mathrm{H}, J=3.2 \mathrm{~Hz}), 7.47(\mathrm{~s}, 1 \mathrm{H}), 7.33(\mathrm{~d}, 1 \mathrm{H}, J=$ $3.2 \mathrm{~Hz}), 7.31-7.25(\mathrm{~m}, 7 \mathrm{H}), 4.24(\mathrm{br}, 1 \mathrm{H}), 3.62(\mathrm{~s}, 2 \mathrm{H}), 2.54-2.49$ $(\mathrm{m}, 4 \mathrm{H}), 1.80-1.76(\mathrm{~m}, 4 \mathrm{H})$; ESI-MS $m / z,(\mathrm{M}+\mathrm{H})^{+} 385$.

( \pm )-(3-Chlorophenyl)[4-(pyrrolidin-1-ylmethyl)phenyl](furan3-yl)methanol (22c). Starting from 12, magnesium turnings, and 20c (268 $\mathrm{mg}, 1.3 \mathrm{mmol})$, the title compound was prepared following the above-described procedure and was obtained as yellow prisms (300 mg, 26\%): mp (EtOAc/n-Hex) $80-81{ }^{\circ} \mathrm{C} ;{ }^{1} \mathrm{H}$ NMR $(300 \mathrm{MHz}$, $\left.\mathrm{CDCl}_{3}\right) \delta 7.44-7.43(\mathrm{~m}, 1 \mathrm{H}), 7.41-7.40(\mathrm{~m}, 1 \mathrm{H}) 7.26(\mathrm{~m}, 5 \mathrm{H})$, 7.23- $7.22(\mathrm{~m}, 3 \mathrm{H}), 7.05$ (dd, $1 \mathrm{H}, J=1.4,0.9 \mathrm{~Hz}), 6.29(\mathrm{dd}, 1 \mathrm{H}$, $J=1.6,0.9 \mathrm{~Hz}), 3.57(\mathrm{~s}, 2 \mathrm{H}), 3.22(\mathrm{br}, 1 \mathrm{H}), 2.50-2.46(\mathrm{~m}, 4 \mathrm{H})$, $1.76-1.72(\mathrm{~m}, 4 \mathrm{H})$; ESI MS $m / z(\mathrm{M}+\mathrm{H})^{+} 368$.

( \pm )-(3-Chlorophenyl)[4-(pyrrolidin-1-ylmethyl)phenyl](pyridin-2-yl)methanol (22d). Starting from 12, magnesium turnings, and $20 \mathrm{~d}$ (413 $\mathrm{mg}, 1.9 \mathrm{mmol})$, the title compound was prepared following the above-described procedure and was obtained as colorless prisms $(340 \mathrm{mg}, 55 \%): \mathrm{mp}$ (EtOAc/n-Hex) $68-69{ }^{\circ} \mathrm{C}$; ${ }^{1} \mathrm{H}$ NMR $\left(300 \mathrm{MHz}, \mathrm{CDCl}_{3}\right) \delta{ }^{1} \mathrm{H}$ NMR $\left(300 \mathrm{MHz}, \mathrm{CDCl}_{3}\right) \delta$ $8.56(\mathrm{~m}, 1 \mathrm{H}), 7.65-7.59(\mathrm{~m}, 1 \mathrm{H}), 7.37-7.01(\mathrm{~m}, 10 \mathrm{H}), 6.36(\mathrm{br}$, $1 \mathrm{H}), 3.60$ (s, 2H), 2.52-2.48 (m, 4H), 1.78-1.74 (m, 4H); ESI-MS $m / z(\mathrm{M}+\mathrm{H})^{+} 379$.

( \pm )-(3-Chlorophenyl)[4-(pyrrolidin-1-ylmethyl)phenyl](pyridin-4-yl)methanol (22e). Starting from 12, magnesium turnings, and 20e $(413 \mathrm{mg}, 1.9 \mathrm{mmol})$, the title compound was prepared following the above-described procedure and was obtained as colorless prisms $(375 \mathrm{mg}, 52 \%)$ : mp (EtOAc/n-Hex) $75-76{ }^{\circ} \mathrm{C} ;{ }^{1} \mathrm{H}$ NMR (300 MHz, $\left.\mathrm{CDCl}_{3}\right) \delta 8.44-8.42(\mathrm{~m}, 2 \mathrm{H}), 7.33-7.20(\mathrm{~m}, 7 \mathrm{H})$, 7.16-7.09 (m, 3H), 3.62 (s, 2H), 2.56-2.52 (m, 4H), 1.80-1.76 (m, $4 \mathrm{H})$; ESI MS $m / z(\mathrm{M}+\mathrm{H})^{+} 379$.

( \pm )-(4-Chlorophenyl)[4-(pyrrolidin-1-ylmethyl)phenyl](thien2-yl)methanol (23a). Starting from 12, magnesium turnings, and 21a (623 mg, $2.8 \mathrm{mmol})$, the title compound was prepared following the above-described procedure and was obtained as colorless prisms (860 mg, 80\%): mp (EtOAc/ $n$-Hex) $69-70{ }^{\circ} \mathrm{C} ;{ }^{1} \mathrm{H}$ NMR $(300 \mathrm{MHz}$, $\left.\mathrm{CDCl}_{3}\right) \delta$ 7.35-7.34 (m, 1H), 7.32-7.31 (m, 1H), 7.28-7.24 (m, $7 \mathrm{H}), 6.92(\mathrm{dd}, 1 \mathrm{H}, J=3.5,4.9 \mathrm{~Hz}), 6.70(\mathrm{dd}, 1 \mathrm{H}, J=1.1,3.5$ 
Hz), 4.39 (br s, 1H), 3.56 (s, 2H), 2.46-2.44 (m, 4H), 1.73-1.70 $(\mathrm{m}, 4 \mathrm{H})$; ESI-MS $\mathrm{m} / \mathrm{z}(\mathrm{M}+\mathrm{H})^{+} 385$.

( \pm )-(4-Chlorophenyl)[4-(pyrrolidin-1-ylmethyl)phenyl](thiazol2-yl)methanol (23b). Starting from 12, magnesium turnings, and 21b $(1.21 \mathrm{~g}, 5.4 \mathrm{mmol})$, the title compound was prepared following the above-described procedure and was obtained as colorless prisms $(1.1 \mathrm{~g}, 55 \%)$ : mp (EtOAc/n-Hex) $78-79{ }^{\circ} \mathrm{C} ;{ }^{1} \mathrm{H} \mathrm{NMR}(300 \mathrm{MHz}$, $\left.\mathrm{CDCl}_{3}\right) \delta 7.70(\mathrm{~d}, 1 \mathrm{H}, J=3.2 \mathrm{~Hz}), 7.34-7.38(\mathrm{~m}, 2 \mathrm{H}), 7.26-7.21$ (m, 7H), 5.61 (br, 1H), 3.53 (s, 2H), $2.42(\mathrm{~m}, 4 \mathrm{H}), 1.70(\mathrm{~m}, 4 \mathrm{H})$. ESI-MS $m / z(\mathrm{M}+1)^{+} 385$.

( \pm )-2-(7-Chloroquinolin-4-yl)-2-phenylacetonitrile (25a). A $60 \%$ oil dispersion of $\mathrm{NaH}(70.0 \mathrm{mg}, 1.74 \mathrm{mmol})$ was washed with Hex and suspended in THF; thereafter, benzylcyanide $(0.17 \mathrm{~mL}$, $1.5 \mathrm{mmol})$ in dry THF (10 mL) was added, and the mixture was heated under reflux for $30 \mathrm{~min}$. Thereafter, compound $24(0.15 \mathrm{~g}$, $0.77 \mathrm{mmol}$ ) was added and the mixture was refluxed until completion. The solvent was evaporated under reduced pressure, the residue was treated with $\mathrm{H}_{2} \mathrm{O}$, neutralized with $5 \%$ acetic acid, and extracted with $\mathrm{CHCl}_{3}$. The organic extracts were dried over $\mathrm{Na}_{2} \mathrm{SO}_{4}$, the solvent was removed, and the residue was purified by flash chromatography, eluting (15\% EtOAC in Hex) to afford 25a $(0.18 \mathrm{~g}, 85 \%)$ as a viscous yellow oil. ${ }^{1} \mathrm{H} \mathrm{NMR}\left(300 \mathrm{MHz}, \mathrm{CDCl}_{3}\right)$ $\delta 8.93(\mathrm{~d}, 1 \mathrm{H}, J=4.5 \mathrm{~Hz}), 8.12(\mathrm{~d}, 1 \mathrm{H}, J=2.1 \mathrm{~Hz}), 7.81(\mathrm{~d}, 1 \mathrm{H}$, $J=8.7 \mathrm{~Hz}$ ), 7.52-7.43 (m, 2H), 7.37-7.26 (m, 5H), 5.77 (s, 1H); ESI-MS $m / z(\mathrm{M}+\mathrm{H})^{+} 279$.

( \pm )-2-(7-Chloroquinolin-4-yl)-2-(4-fluorophenyl)acetonitrile (25b). Starting from $24(0.45 \mathrm{~g}, 2.3 \mathrm{mmol})$ and 4-fluorophenylacetonitrile $(0.55 \mathrm{~mL}, 4.6 \mathrm{mmol})$, the title compound was prepared following the above-described procedure and was obtained as a viscous yellow oil $(0.58 \mathrm{~g}, 85 \%):{ }^{1} \mathrm{H} \mathrm{NMR}\left(300 \mathrm{MHz}, \mathrm{CDCl}_{3}\right) \delta$ $8.97(\mathrm{~d}, 1 \mathrm{H}, J=4.8 \mathrm{~Hz}), 8.17(\mathrm{~d}, 1 \mathrm{H}, J=2.4 \mathrm{~Hz}), 7.78(\mathrm{~d}, 1 \mathrm{H}$, $J=9.0 \mathrm{~Hz}), 7.53-7.49(\mathrm{~m}, 2 \mathrm{H}), 7.33-7.26(\mathrm{~m}, 2 \mathrm{H}), 7.11-7.04(\mathrm{~m}$, 2H), $5.75(\mathrm{~s}, 1 \mathrm{H})$; ESI-MS $\mathrm{m} / z(\mathrm{M}+\mathrm{H})^{+} 297$.

(7-Chloroquinolin-4-yl)phenylmethanone (26a). A $60 \%$ oil dispersion of $\mathrm{NaH}(0.31 \mathrm{~g}, 0.79 \mathrm{mmol})$ was washed with Hex and suspended in THF; thereafter, 25a $(0.220 \mathrm{~g}, 0.79 \mathrm{mmol})$ in dry THF $(10 \mathrm{~mL})$ was added at $\mathrm{rt}$ and stirred for $5 \mathrm{~min}$, until evolution of $\mathrm{H}_{2}$ ceased. A current of $\mathrm{O}_{2}$ was passed into the yellow solution until the solution turn to colorless. The solvent was evaporated under reduced pressure and residue was treated with $\mathrm{H}_{2} \mathrm{O}$ and extracted with $\mathrm{CHCl}_{3}$. The organic extracts were dried over $\mathrm{Na}_{2} \mathrm{SO}_{4}$, the solvent was removed under reduced pressure and the residue was purified by flash chromatography (15\% EtOAc in Hex) to afford 26a as a viscous oil $(0.20 \mathrm{~g}, 93 \%):{ }^{1} \mathrm{H}$ NMR $\left(300 \mathrm{MHz}, \mathrm{CDCl}_{3}\right) \delta$ $8.98(\mathrm{~d}, 1 \mathrm{H}, J=6.3 \mathrm{~Hz}), 8.15(\mathrm{~d}, 1 \mathrm{H}, J=2.4 \mathrm{~Hz}), 7.81-7.78(\mathrm{~m}$, $3 \mathrm{H}), 7.64-7.58(\mathrm{~m}, 1 \mathrm{H}), 7.48-7.42(\mathrm{~m}, 3 \mathrm{H}), 7.37(\mathrm{~d}, 1 \mathrm{H}, J=4.2$ $\mathrm{Hz})$.

(7-Chloroquinolin-4-yl)(4-fluorophenyl)methanone (26b). Starting from $25 \mathrm{~b}(0.46 \mathrm{~g}, 1.56 \mathrm{mmol})$, the title compound was prepared following the above-described procedure and was obtained as a viscous oil $(0.36 \mathrm{~g}, 90 \%)$ : ${ }^{1} \mathrm{H}$ NMR $\left(300 \mathrm{MHz}, \mathrm{CDCl}_{3}\right) \delta 9.03$ (d, $1 \mathrm{H}, J=4.2 \mathrm{~Hz}), 8.20(\mathrm{~d}, 1 \mathrm{H}, J=2.4 \mathrm{~Hz}), 7.89-7.79(\mathrm{~m}, 3 \mathrm{H})$, $7.52-7.48(\mathrm{~m}, 1 \mathrm{H}), 7.39(\mathrm{~d}, 1 \mathrm{H}, J=4.5 \mathrm{~Hz}), 7.19-7.13(\mathrm{~m}, 2 \mathrm{H})$.

( \pm )-[4-(Pyrrolidin-1-ylmethyl)phenyl](7-chloroquinolin-4yl)phenylmethanol (27a). Starting from 12, magnesium turnings, and 26a $(0.209 \mathrm{~g}, 0.78 \mathrm{mmol})$, the title compound was prepared as described for 17a and was obtained as colorless prisms $(0.11 \mathrm{~g}$, $32 \%$ ): mp (EtOAc/n-Hex) $124-125{ }^{\circ} \mathrm{C}$; ${ }^{1} \mathrm{H}$ NMR $(300 \mathrm{MHz}$, $\left.\mathrm{CDCl}_{3}\right) \delta 8.64(\mathrm{~d}, 1 \mathrm{H}, J=4.8 \mathrm{~Hz}), 8.10(\mathrm{~d}, 1 \mathrm{H}, J=9.0 \mathrm{~Hz}), 8.02$ $(\mathrm{d}, 1 \mathrm{H}, J=2.4 \mathrm{~Hz}), 7.38-7.16(\mathrm{~m}, 10 \mathrm{H}), 6.79(\mathrm{~d}, 1 \mathrm{H}, J=4.8$ $\mathrm{Hz}), 3.98$ (br, 1H), $3.61(\mathrm{~s}, 2 \mathrm{H}), 2.52(\mathrm{~m}, 4 \mathrm{H}), 1.80-1.75(\mathrm{~m}, 4 \mathrm{H})$; ESI MS $m / z(\mathrm{M}+\mathrm{H})^{+} 429$.

( \pm )-(4-Fluorophenyl)[4-(pyrrolidin-1-ylmethyl)phenyl](7-chloroquinolin-4-yl)methanol (27b). Starting from 12, magnesium turnings, and $\mathbf{2 6 b}(0.485 \mathrm{~g}, 1.7 \mathrm{mmol})$, the title compound was prepared following the above-described procedure and was obtained as colorless prisms $(0.30 \mathrm{~g}, 40 \%)$ : $\mathrm{mp}($ EtOAc/n-Hex $) 110-111^{\circ} \mathrm{C}$; ${ }^{1} \mathrm{H}$ NMR $\left(300 \mathrm{MHz}, \mathrm{CDCl}_{3}\right) \delta 8.65(\mathrm{~d}, 1 \mathrm{H}, J=4.5 \mathrm{~Hz}), 8.06(\mathrm{~d}$, $1 \mathrm{H}, J=9.3 \mathrm{~Hz}), 8.03(\mathrm{~d}, 1 \mathrm{H}, J=2.1 \mathrm{~Hz}), 7.32-6.98(\mathrm{~m}, 9 \mathrm{H})$, $6.78(\mathrm{~d}, 1 \mathrm{H}, J=4.8 \mathrm{~Hz}), 3.93(\mathrm{bs}, 1 \mathrm{H}), 3.61(\mathrm{~s}, 2 \mathrm{H}), 2.52(\mathrm{~m}$, $4 \mathrm{H}), 1.79-1.77(\mathrm{~m}, 4 \mathrm{H})$; ESI MS $m / z(\mathrm{M}+\mathrm{H})^{+} 447$.
( \pm )-1-\{(4-Chlorophenyl) [4-( $N, N$-diethylaminomethyl $)$ phenyl]phenylmethyl $\}$ - $\mathbf{H}$-imidazole (4a). To a solution of $\mathbf{1 7 a}$ (323 $\mathrm{mg}, 0.85 \mathrm{mmol})$ and a drop of DMF in dry DCM $(15 \mathrm{~mL})$, cooled to $0{ }^{\circ} \mathrm{C}$, was added $\mathrm{SOCl}_{2}(180 \mu \mathrm{L}, 2.5 \mathrm{mmol})$ in dry DCM (10 $\mathrm{mL}$ ), and the mixture was stirred at $0{ }^{\circ} \mathrm{C}$ for $20 \mathrm{~min}$ and thereafter was heated to $45^{\circ} \mathrm{C}$ for $4 \mathrm{~h}$. The volatiles were removed and the residue was treated with dry $\mathrm{MeCN}$ and concentrated under reduced pressure to remove residual $\mathrm{SOCl}_{2}$. The resulting hydrochloride salt (360 mg, $0.85 \mathrm{mmol}$ ) was suspended in dry MeCN (20 mL) and to this solution was slowly added a solution containing $\mathrm{Et}_{3} \mathrm{~N}$ (580 $\mu \mathrm{L}, 4.2 \mathrm{mmol})$ and imidazole $(280 \mathrm{mg}, 4.2 \mathrm{mmol})$ in $\mathrm{MeCN}(10$ $\mathrm{mL}$ ) at $0{ }^{\circ} \mathrm{C}$. Thereafter, the reaction mixture was heated to $80^{\circ} \mathrm{C}$ for $4 \mathrm{~h}$. The solvent was evaporated under reduced pressure and the residue was treated with water and extracted with EtOAc. The combined organic extracts were dried over $\mathrm{Na}_{2} \mathrm{SO}_{4}$ and concentrated. The crude residue was purified by flash column chromatography $\left(2 \% \mathrm{MeOH}\right.$ in $\left.\mathrm{CHCl}_{3}\right)$ to afford $\mathbf{4 a}$ as a yellow oil (30.0 mg, 26\% yield): ${ }^{1} \mathrm{H}$ NMR $\left(200 \mathrm{MHz}, \mathrm{CDCl}_{3}\right) \delta 7.43(\mathrm{~s}, 1 \mathrm{H})$, 7.32-7.27 (m, 7H), 7.13-7.04 (m, 7H), $6.79(\mathrm{~s}, 1 \mathrm{H}), 3.58(\mathrm{~s}, 2 \mathrm{H})$, $2.55(\mathrm{q}, 4 \mathrm{H}, J=7.0 \mathrm{~Hz}), 1.05(\mathrm{t}, 6 \mathrm{H}, J=7.0 \mathrm{~Hz})$; ESI-MS m/z, $(\mathrm{M}-\text { imidazole })^{+}$364. Anal. $\left(\mathrm{C}_{27} \mathrm{H}_{28} \mathrm{ClN}_{3}\right) \mathrm{C}, \mathrm{H}, \mathrm{N}$.

( \pm )-1-\{(4-Chlorophenyl)[4-(morpholin-4-ylmethyl)phenyl]phenylmethyl $\}$ - $1 \boldsymbol{H}$-imidazole (4b). Starting from $\mathbf{1 7 b}(351 \mathrm{mg}, 0.89$ $\mathrm{mmol}$ ), the title compound was prepared following the abovedescribed procedure and was obtained as a light yellow viscous oil (260 mg, 66\%): ${ }^{1} \mathrm{H}$ NMR (300 MHz, $\left.\mathrm{CDCl}_{3}\right) \delta 7.41(\mathrm{~s}, 1 \mathrm{H})$, 7.31-7.25 (m, 7H), 7.10-7.03 (m, 7H), $6.77(\mathrm{~m}, 1 \mathrm{H}), 3.68(\mathrm{~m}, 4 \mathrm{H})$, $3.47(\mathrm{~s}, 2 \mathrm{H}), 2.42(\mathrm{~m}, 4 \mathrm{H})$; ESI MS $\mathrm{m} / \mathrm{z}(\mathrm{M}-\text { imidazole })^{+} 376$. Anal. $\left(\mathrm{C}_{27} \mathrm{H}_{26} \mathrm{ClN}_{3} \mathrm{O}\right) \mathrm{C}, \mathrm{H}, \mathrm{N}$.

$( \pm)$-1-\{(4-Chlorophenyl)[4-(piperazin-4-ylmethyl)phenyl]phenylmethyl $\}$ - $1 \boldsymbol{H}$-imidazole $(\mathbf{4 c})$. Starting from $\mathbf{1 7 c}$ (286 mg, 0.58 $\mathrm{mmol}$ ), the title compound was prepared following the abovedescribed procedure and was obtained as a brown amorphous solid (138 mg, 53\%): ${ }^{1} \mathrm{H}$ NMR (300 MHz, $\left.\mathrm{CDCl}_{3}\right) \delta 7.40(\mathrm{~s}, 1 \mathrm{H})$, 7.30-7.24 (m, 8H), 7.09-7.01 (m, 6H), $6.76(\mathrm{~m}, 1 \mathrm{H}), 3.46(\mathrm{~s}, 2 \mathrm{H})$, $2.84(\mathrm{~m}, 4 \mathrm{H}), 2.38(\mathrm{~m}, 4 \mathrm{H}), 1.73(\mathrm{br}, 1 \mathrm{H})$; ESI MS m/z $(\mathrm{M}-$ imidazole $)^{+}$375. Anal. $\left(\mathrm{C}_{27} \mathrm{H}_{27} \mathrm{ClN}_{4}\right) \mathrm{C}, \mathrm{H}, \mathrm{N}$.

$( \pm)$-1-\{(4-Chlorophenyl)(4-fluorophenyl)[4-(pyrrolidin-1-ylmethyl)phenyl]methyl\}-1H-imidazole (4d). Starting from 18a $(0.348 \mathrm{~g}, 0.88 \mathrm{mmol})$, the title compound was prepared as described for $4 \mathbf{a}$ and was obtained as brown oil $(0.35 \mathrm{~g}, 88 \%)$ : ${ }^{1} \mathrm{H}$ NMR $\left(300 \mathrm{MHz}, \mathrm{CDCl}_{3}\right) \delta 7.39(\mathrm{~s}, 1 \mathrm{H}), 7.31-7.26(\mathrm{~m}, 4 \mathrm{H}), 7.08-6.99$ (m, 9H), 6.75 (s, 1H), 3.60 (s, 2H), 2.53-2.49 (m, 4H), 1.79-1.75 $(\mathrm{m}, 4 \mathrm{H})$; ESI MS $m / z,(\mathrm{M}-\text { imidazole })^{+}$378. Anal. $\left(\mathrm{C}_{27} \mathrm{H}_{25} \mathrm{ClFN}_{3}\right)$ C, H, N.

1-\{(4-Chlorophenyl)bis[4-(pyrrolidin-1-ylmethyl)phenyl]methyl\}-1H-imidazole (4e). Starting from $\mathbf{1 8 b}(143 \mathrm{mg}, 0.31 \mathrm{mmol})$, the title compound was prepared following the above-described procedure and was obtained as brown oil $(100 \mathrm{mg}, 65 \%):{ }^{1} \mathrm{H}$ NMR $\left(200 \mathrm{MHz}, \mathrm{CDCl}_{3}\right) \delta 7.40(\mathrm{~s}, 1 \mathrm{H}), 7.31-7.25(\mathrm{~m}, 6 \mathrm{H}), 7.06-7.01$ (m, 8H), 3.62 (s, 4H), $2.53(\mathrm{~m}, 8 \mathrm{H}), 1.78(\mathrm{~m}, 8 \mathrm{H})$; ESI MS m/z (M - imidazole $)^{+}$444. Anal. $\left(\mathrm{C}_{32} \mathrm{H}_{35} \mathrm{ClN}_{4}\right) \mathrm{C}, \mathrm{H}, \mathrm{N}$.

( \pm )-1-\{(3-Chlorophenyl)[4-(pyrrolidin-1-ylmethyl)phenyl](thien-2-yl)methyl\}-1H-imidazole (4f). Starting from 22a (0.345 g, $0.90 \mathrm{mmol})$, the title compound was prepared following the abovedescribed procedure and was obtained as a brown oil $(77.0 \mathrm{mg}$, 20\%): ${ }^{1} \mathrm{H}$ NMR $\left(300 \mathrm{MHz}, \mathrm{CDCl}_{3}\right) \delta 7.40(\mathrm{~m}, 1 \mathrm{H}), 7.37-7.30(\mathrm{~m}$, $4 \mathrm{H})$, 7.27-7.25 (m, 1H), 7.13-7.12 (m, 1H), 7.09-7.07 (m, 2H), 7.06-7.05 (m, 1H), 7.03-6.99 (m, 2H), 6.88-6.85 (m, 2H), 3.63 (s, 2H), 2.54-2.50 (m, 4H), 1.81-1.77 (m, 4H); ESI MS m/z, (M - imidazole $)^{+}$366. Anal. $\left(\mathrm{C}_{25} \mathrm{H}_{24} \mathrm{ClN}_{3} \mathrm{~S}\right) \mathrm{C}, \mathrm{H}, \mathrm{N}$.

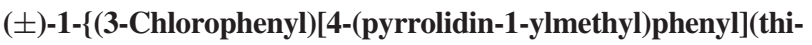
azol-2-yl)methyl\}-1H-imidazole (4g). Starting from 22b $(0.60 \mathrm{~g}$, $1.56 \mathrm{mmol}$ ), the title compound was prepared following the abovedescribed procedure and was obtained as a colorless oil $(0.50 \mathrm{~g}$, 74\%): ${ }^{1} \mathrm{H}$ NMR $\left(400 \mathrm{MHz}, \mathrm{CDCl}_{3}\right) \delta 7.92(\mathrm{~d}, 1 \mathrm{H}, J=3.2 \mathrm{~Hz})$, $7.55(\mathrm{~s}, 1 \mathrm{H}), 7.37-7.23(\mathrm{~m}, 5 \mathrm{H}), 7.11-6.94(\mathrm{~m}, 6 \mathrm{H}), 3.63(\mathrm{~s}, 2 \mathrm{H})$, 2.58-2.45 (m, 4H), 1.87-1.76 (m, 4H); ESI-MS $\mathrm{m} / \mathrm{z}(\mathrm{M}-$ imidazole $)^{+}$367. Anal. $\left(\mathrm{C}_{24} \mathrm{H}_{23} \mathrm{ClN}_{4} \mathrm{~S}\right) \mathrm{C}, \mathrm{H}, \mathrm{N}$. 
( \pm )-1-\{(3-Chlorophenyl)[4-(pyrrolidin-1-ylmethyl)phenyl](furan-3-yl)methyl\}-1H-imidazole (4h). Starting from 22c $(0.184 \mathrm{~g}$, $0.50 \mathrm{mmol}$ ), the title compound was prepared following the abovedescribed procedure and was obtained as a colorless oil $(42.0 \mathrm{mg}$, 20\%): ${ }^{1} \mathrm{H}$ NMR (300 MHz, $\left.\mathrm{CDCl}_{3}\right) \delta 7.48-7.47$ (m, 1H), 7.33-7.29 (m, 4H), $7.26(\mathrm{~m}, 2 \mathrm{H}), 7.13(\mathrm{~m}, 2 \mathrm{H}), 7.08(\mathrm{~m}, 1 \mathrm{H}), 7.03(\mathrm{~m}, 1 \mathrm{H})$, $7.01(\mathrm{~m}, 1 \mathrm{H}), 6.96-6.94(\mathrm{~m}, 1 \mathrm{H}), 6.26(\mathrm{~s}, 1 \mathrm{H}), 3.62(\mathrm{~s}, 2 \mathrm{H}), 2.52$ $(\mathrm{m}, 4 \mathrm{H}), 1.79(\mathrm{~m}, 4 \mathrm{H})$; ESI MS m/z $(\mathrm{M}-\text { imidazole })^{+} 350$. Anal. $\left(\mathrm{C}_{25} \mathrm{H}_{24} \mathrm{ClN}_{3} \mathrm{O}\right) \mathrm{C}, \mathrm{H}, \mathrm{N}$.

( \pm )-1-\{(3-Chlorophenyl)[4-(pyrrolidin-1-ylmethyl)phenyl](pyridin-2-yl)methyl $\}$ - $1 \boldsymbol{H}$-imidazole (4i). Starting from 22d $(0.417$ $\mathrm{g}, 1.1 \mathrm{mmol}$ ), the title compound was prepared following the abovedescribed procedure and was obtained as a colorless oil $(200 \mathrm{mg}$, 42\%): ${ }^{1} \mathrm{H}$ NMR (300 MHz, $\left.\mathrm{CDCl}_{3}\right) \delta 8.69-8.66(\mathrm{~m}, 1 \mathrm{H}), 7.69-7.63$ $(\mathrm{m}, 1 \mathrm{H}), 7.58-7.57(\mathrm{~m}, 1 \mathrm{H}), 7.31-7.23(\mathrm{~m}, 5 \mathrm{H}), 7.10-7.04(\mathrm{~m}, 3 \mathrm{H})$, 6.99-6.91 (m, 4H), 3.60 (s, 2H), 2.52-2.48 (m, 4H), 1.79 (m, 4H); ESI-MS $m / z(\mathrm{M}-\text { imidazole })^{+}$361. Anal. $\left(\mathrm{C}_{26} \mathrm{H}_{25} \mathrm{ClN}_{4}\right) \mathrm{C}, \mathrm{H}, \mathrm{N}$.

$( \pm)-1-\{(3-C h l o r o p h e n y l)[4-(p y r r o l i d i n-1-y l m e t h y l) p h e n y l](p y-$ ridin-4-yl)methyl $\}$ - $1 \boldsymbol{H}$-imidazole $(\mathbf{4 j})$. Starting from $22 \mathrm{e}(0.379$ $\mathrm{g}, 1.0 \mathrm{mmol}$ ), the title compound was prepared as described for $\mathbf{4 a}$ and was obtained as a colorless oil (230 mg, 53\%): ${ }^{1} \mathrm{H}$ NMR (300 $\left.\mathrm{MHz}, \mathrm{CDCl}_{3}\right) \delta 8.63(\mathrm{~d}, 2 \mathrm{H}, J=6.2 \mathrm{~Hz}), 7.42-7.26(\mathrm{~m}, 6 \mathrm{H})$, 7.10-7.04 (m, 6H), 6.78 (s, 1H), 3.68 (s, 2H), 2.59 (m, 4H), 1.83 $(\mathrm{m}, 4 \mathrm{H})$; ESI MS m/z $(\mathrm{M}-\text { imidazole })^{+}$361. Anal. $\left(\mathrm{C}_{26} \mathrm{H}_{25} \mathrm{ClN}_{4}\right)$ $\mathrm{C}, \mathrm{H}, \mathrm{N}$.

( \pm )-1-\{(4-Chlorophenyl)[4-(pyrrolidin-1-ylmethyl)phenyl](thien-2-yl)methyl\}-1H-imidazole (4k). Starting from 23a (0.883 g, $2.3 \mathrm{mmol})$, the title compound was prepared following the abovedescribed procedure and was obtained as a colorless oil $(150 \mathrm{mg}$, 15\%): ${ }^{1} \mathrm{H}$ NMR $\left(200 \mathrm{MHz}, \mathrm{CDCl}_{3}\right) \delta 7.40(\mathrm{~s}, 1 \mathrm{H}), 7.34-7.27(\mathrm{~m}$, 5H), 7.10-7.04 (m, 5H), 7.00 (dd, 1H, $J=3.8,5.2 \mathrm{~Hz}), 6.86$ (dd, $1 \mathrm{H}, J=1.1,3.8 \mathrm{~Hz}), 6.85(\mathrm{~s}, 1 \mathrm{H}), 3.63(\mathrm{~s}, 2 \mathrm{H}), 2.55-2.50(\mathrm{~m}$, 4H), 1.81-1.77 (m, 4H); ESI-MS m/z (M - imidazole $)^{+} 366$. Anal. $\left(\mathrm{C}_{25} \mathrm{H}_{24} \mathrm{ClN}_{3} \mathrm{~S}\right) \mathrm{C}, \mathrm{H}, \mathrm{N}$.

$( \pm)$-1-\{(4-Chlorophenyl)[4-(pyrrolidin-1-ylmethyl)phenyl](thiazol-2-yl)methyl\}-1 $\boldsymbol{H}$-imidazole (4I). Starting from 23b $(0.355 \mathrm{~g}$, $1.0 \mathrm{mmol}$ ), the title compound was prepared following the abovedescribed procedure and was obtained as a colorless oil $(0.32 \mathrm{~g}$, $72 \%):{ }^{1} \mathrm{H}$ NMR $\left(300 \mathrm{MHz}, \mathrm{CDCl}_{3}\right) \delta 7.89(\mathrm{~d}, 1 \mathrm{H}, J=3.4 \mathrm{~Hz})$, $7.53(\mathrm{~m}, 1 \mathrm{H}), 7.36-7.26(\mathrm{~m}, 5 \mathrm{H}), 7.08-6.98(\mathrm{~m}, 6 \mathrm{H}), 3.58(\mathrm{~s}, 2 \mathrm{H})$, 2.48-2.44 (m, 4H), 1.75-1.71 (m, 4H); ESI-MS m/z (M imidazole $)^{+}$367. Anal. $\left(\mathrm{C}_{24} \mathrm{H}_{23} \mathrm{ClN}_{4} \mathrm{~S}\right) \mathrm{C}, \mathrm{H}, \mathrm{N}$.

( \pm )-1-\{[4-(Pyrrolidin-1-ylmethyl)phenyl](7-chloroquinolin-4yl)phenylmethyl $\}$ - $1 \boldsymbol{H}$-imidazole $\mathbf{( 4 m )}$. Starting from $\mathbf{2 7 a}(90.1 \mathrm{mg}$, $0.21 \mathrm{mmol}$ ), the title compound was prepared as described for $\mathbf{4 a}$ and was obtained as a brown oil $(57.0 \mathrm{mg}, 52 \%):{ }^{1} \mathrm{H}$ NMR (300 $\left.\mathrm{MHz}, \mathrm{CDCl}_{3}\right) \delta 8.87(\mathrm{~d}, 1 \mathrm{H}, J=4.5 \mathrm{~Hz}), 8.12(\mathrm{~d}, 1 \mathrm{H}, J=2.4$ $\mathrm{Hz}), 7.39-7.07(\mathrm{~m}, 13 \mathrm{H}), 6.87(\mathrm{~d}, 1 \mathrm{H}, J=4.8 \mathrm{~Hz}), 6.73(\mathrm{~s}, 1 \mathrm{H})$, $3.61(\mathrm{~s}, 2 \mathrm{H}), 2.52(\mathrm{~m}, 4 \mathrm{H}), 1.81-1.77(\mathrm{~m}, 4 \mathrm{H})$; ESI MS m/z $(\mathrm{M}-$ imidazole $)^{+}$411. Anal. $\left(\mathrm{C}_{30} \mathrm{H}_{27} \mathrm{ClN}_{4}\right) \mathrm{C}, \mathrm{H}, \mathrm{N}$.

( \pm )-1-\{(4-Fluorophenyl)[4-(pyrrolidin-1-ylmethyl)phenyl](7chloroquinolin-4-yl)methyl\}-1 $\boldsymbol{H}$-imidazole (4n). Starting from $\mathbf{2 7} \mathbf{b}$ $(0.380 \mathrm{~g}, 0.85 \mathrm{mmol})$, the title compound was prepared following the above-described procedure and was obtained as a brown amorphous solid $(0.25 \mathrm{~g}, 60 \%):{ }^{1} \mathrm{H}$ NMR $\left(300 \mathrm{MHz}, \mathrm{CDCl}_{3}\right) \delta$ $8.86(\mathrm{~d}, 1 \mathrm{H}, J=4.8 \mathrm{~Hz}), 8.10(\mathrm{~d}, 1 \mathrm{H}, J=1.8 \mathrm{~Hz}), 7.36-7.38(\mathrm{~m}$, $3 \mathrm{H}), 7.10-6.99(\mathrm{~m}, 9 \mathrm{H}), 6.83(\mathrm{~d}, 1 \mathrm{H}, J=4.8 \mathrm{~Hz}), 6.70(\mathrm{~s}, 1 \mathrm{H})$, $3.60(\mathrm{~s}, 2 \mathrm{H}), 2.50(\mathrm{~m}, 4 \mathrm{H}), 1.77(\mathrm{~m}, 4 \mathrm{H})$; ESI MS m/z $(\mathrm{M}-$ imidazole $)^{+}$429. Anal. $\left(\mathrm{C}_{30} \mathrm{H}_{26} \mathrm{ClFN}_{4}\right) \mathrm{C}, \mathrm{H}, \mathrm{N}$.

( \pm )-1-\{(4-Chlorophenyl)[4-(pyrrolidin-1-ylmethyl)phenyl]phenylmethyl $\}-1 H$-benzo[d $]$ imidazole (4o). Starting from $17 \mathbf{c}^{6}(94.0$ $\mathrm{mg}, 0.22 \mathrm{mmol}$ ) and $1 H$-benzo[d]imidazole, the title compound was prepared following the above-described procedure and was obtained as brown oil (51.0 mg, 51\%): ${ }^{1} \mathrm{H}$ NMR $\left(200 \mathrm{MHz}, \mathrm{CDCl}_{3}\right) \delta 7.83$ $(\mathrm{s}, 1 \mathrm{H}), 7.77(\mathrm{~d}, 1 \mathrm{H}, J=8.1 \mathrm{~Hz}), 7.32-7.25(\mathrm{~m}, 7 \mathrm{H}), 7.19-7.06$ $(\mathrm{m}, 7 \mathrm{H}), 6.93-6.86(\mathrm{~m}, 1 \mathrm{H}), 6.44(\mathrm{~d}, 1 \mathrm{H}, J=8.3 \mathrm{~Hz}), 3.59(\mathrm{~s}$, 2H), $2.50(\mathrm{~m}, 4 \mathrm{H}), 1.81-1.76(\mathrm{~m}, 4 \mathrm{H})$; ESI MS m/z (M benzimidazole $)^{+}$360. Anal. $\left(\mathrm{C}_{31} \mathrm{H}_{28} \mathrm{ClN}_{3}\right) \mathrm{C}, \mathrm{H}, \mathrm{N}$.

( \pm -1-\{(4-Chlorophenyl)[4-(pyrrolidin-1-ylmethyl)phenyl]phenylmethyl\}piperazine (4p). Starting from 17c6 (94.0 mg, 0.22 $\mathrm{mmol}$ ) and piperazine, the title compound was prepared following the above-described procedure and was obtained as brown oil (51.0 $\mathrm{mg}, 51 \%)$ : ${ }^{1} \mathrm{H}$ NMR (200 MHz, $\left.\mathrm{CDCl}_{3}\right) 7.42-7.15(\mathrm{~m}, 13 \mathrm{H}), 3.55$ (s, 2H), $2.99(\mathrm{~m}, 6 \mathrm{H}), 2.52(\mathrm{~m}, 4 \mathrm{H}), 2.22(\mathrm{~m}, 3 \mathrm{H}), 1.79-1.76(\mathrm{~m}$, $4 \mathrm{H})$; ESI MS m/z $(\mathrm{M}-\text { piperazine })^{+} 360$. Anal. $\left(\mathrm{C}_{28} \mathrm{H}_{32} \mathrm{ClN}_{3}\right) \mathrm{C}$, $\mathrm{H}, \mathrm{N}$.

1. Molecular Modeling. Molecular modeling calculations were performed on SGI Origin 200 8XR12000, while molecular modeling graphics were carried out on SGI Octane 2 and Octane workstations.

Apparent $\mathrm{p} K_{\mathrm{a}}$ values of CQ, CLT, 2, 3g, 4q,r, and the newly designed compounds $(\mathbf{3 a}-\mathbf{f}$ and $\mathbf{4} \mathbf{a}-\mathbf{p})$ were calculated by using the $\mathrm{ACD} / \mathrm{p} K_{\mathrm{a}} \mathrm{DB}$ version 10.00 software (Advanced Chemistry Development Inc., Toronto, Canada), accordingly, percentage of neutral/ionized forms were computed at $\mathrm{pH} 7.4$ (blood), 7.2 (cytoplasm), and 5.5 (Pffood vacuole) using the Handerson-Hasselbach equation.

All the compounds were built taking into account the prevalent ionic forms at the considered different $\mathrm{pH}$ values using the Insight 2005 Builder module.

Partial charges of the compounds, considered protonated at the imidazole and benzimidazole moieties as consequence of the estimation of apparent $\mathrm{p} K_{\mathrm{a}}$ values, were assigned by comparing partial charges assigned by CFF91 force field ${ }^{32}$ with those calculated by $\mathrm{MNDO}^{33}$ semiempirical 1 SCF calculations performed on the neutral and the ionized compounds. In particular, CFF91 force field partial charges were added to the algebraic difference between MNDO partial charges of the protonated form and MNDO partial charge of the neutral form.

The conformational space of all compounds was sampled through 200 cycles of simulated annealing (CFF91 force field ${ }^{32}$ ) by following our standard protocol. The system was heated up to 1000 $\mathrm{K}$ over $2000 \mathrm{fs}$ (time step $=3.0$ ); the temperature of $1000 \mathrm{~K}$ was applied to the system for $2000 \mathrm{fs}$ (time step = 3.0), with the aim of surmounting torsional barriers; successively, temperature was linearly reduced to $300 \mathrm{~K}$ in $1000 \mathrm{fs}$ (time step =1.0). Resulting structures were subjected to energy minimization within Insight 2005 Discover 3 module (CFF91 force field, ${ }^{32}$ conjugate gradient algorithm $;{ }^{34} \epsilon=80 * \mathrm{r}$ ) until the maximum rms derivative was less than $0.001 \mathrm{kcal} / \AA$ and subsequently ranked in different families, taking into account their (i) conformational energy and (ii) torsional angles values, with the exception of those of lateral chains.

To properly analyze the electronic properties, the most stable conformer of each family was subjected to a full geometry optimization by semiempirical calculations, using the quantum mechanical method AM1 in the Mopac 6.0 package $^{35}$ in Ampac/ Mopac module of Insight 2000.1. GNORM value was set to 0.5. To reach a full geometry optimization, the criteria for terminating all optimizations was increased by a factor of 100 using the keyword PRECISE.

The dipole moments were calculated using partial charges obtained by the quantum mechanical method AM1 (Ampac/Mopac, Accelrys, San Diego) and visualized as vector (Decipher, Accelrys, San Diego). Connolly surfaces were computed and colored by AM1 charge distribution. $\log \mathrm{D}$ values of $\mathbf{2}$ and $\mathbf{4 e}$ at $\mathrm{pH} 7.4$ (blood), 7.2 (cytoplasm), and 5.5 ( $P f \mathrm{FV}$ ) were calculated by using the $\mathrm{ACD} /$ $\mathrm{p} K_{\mathrm{a}} \mathrm{DB}$ version 10.00 software (Advanced Chemistry Development Inc., Toronto, Canada).

Docking studies were carried out on CLT (global minimum conformer) into the homology model ${ }^{26}$ of lanosterol $14 \alpha$-demethylase of $C$. Albicans using a docking methodology (Affinity, SA_Docking; Insight2005, Accelrys, San Diego) that considers all the systems (i.e., ligand and protein) flexible. Heme29.frc, ${ }^{26}$ a forcefield including heme parameters, was used during all molecular simulations. Although in the subsequent flexible docking protocol all the systems were perturbed by means of Monte Carlo and simulated annealing procedures, nevertheless, the flexible docking procedure formally requires a reasonable starting structure. Accordingly, CLT was manually positioned into the active site, taking into account the binding mode of fluconazole (PDB code: 1EA1) and ketoconazole (PDB code:1JIN) in cytochromes P450. The obtained complex was subjected to preliminary energy minimization (steepest descendent algorithm; $\epsilon=80 *$ r) until the maximum rms 
derivative was less than $5 \mathrm{kcal} / \AA$ to generate roughly docked starting structure, as required by the Affinity docking procedure. Successively, flexible docking was achieved through the Affinity module in the Insight2005 suite, using the SA_Docking procedure ${ }^{36}$ and using the Cell_Multipole ${ }^{37}$ method for nonbond interactions. Lanosterol $14 \alpha$-demethylase binding domain area was defined as a flexible subset around the ligand containing all residues having at least one atom within a $6 \AA$ radius from any given ligand atom. All atoms included in the binding domain area and the ligand were left free to move during the entire docking calculations, with the exception of the coordinating nitrogen, heme pyrroles, and the iron, which were tethered with a force constant of $30 \mathrm{kcal} / \AA^{2}$. A Monte Carlo/minimization approach for random generation of a maximum of 20 structures was used, with an energy tolerance of $10^{6} \mathrm{kcal} /$ mol to ensure a wide variance of the input structures to be minimized ( 2500 iterations; $\epsilon=80 * \mathrm{r}$ ). During this step, the ligand is moved by a random combination of translation, rotation, and torsional changes (Flexible_Ligand option, considering all rotatable bonds), to sample both the conformational space of the ligand and its orientation with respect to the enzyme. Van der Waals (vdW) and coulombic terms were scaled to a factor of 0.1 to avoid very severe divergences in the coulombic and vdW energies. The Metropolis test, at a temperature of $310 \mathrm{~K}$, and a structure similarity check (rms tolerance $=0.3 \mathrm{kcal} / \AA ̊ \AA)$ were applied to select acceptable structures. A total of 50 stages of simulated annealing (100 fs each) were applied on the resulting complexes. Over the course of the simulated annealing, system temperature was linearly decreased from 500 to $300 \mathrm{~K}$; concurrently, the van der Waals and coulombic scale factors were similarly decreased from their initial values (defined above as 0.1 ) to their final value (1.0). A final round of $10^{5}$ minimization steps was applied at the end of the molecular dynamics. Resulting docked complexes were ranked by their conformational energy, and the geometry of imidazole-iron coordination bond. The coordination bond distances and angles were compared with those found by analyzing the iron-imidazole complexes found in CSDS (Cambridge Structural Database System, CSDS codes: CELWIZ, FEWXAG, KIWNIN, SIBZIM, SIBZOS, YILZIC, YILZOI, YIMYUO). The lowest energy complex showing the best coordination geometry was selected as representing structure for the most probable binding mode. Connolly surface was computed and colored on the basis of amino acids formal charge.

The experimentally determined structures of cytochromes P450 (PDB IDs: 1EA1, 1JIN, 1E9X, 1OXA, 1W0E, 1W0F, 1W0G) were downloaded from the Protein Data Bank (PDB; http://www.rcsb.org/ $\mathrm{pdb} /$ ). Hydrogens were added to all the PDB structures, considering a $\mathrm{pH}$ value of 7.2. P450 X-ray structures were superimposed by fitting heme atoms.

The sequences of cytochromes P450 were downloaded from the Sequence Retrieval System (http://srs.embl-heidelberg.de:8000/ srs5). Sequence alignments were performed using ClustalW (WWW service at the European Bioinformatics Institute, http://www.ebi. ac.uk/clustalw) and Multiple_Alignment (Accelrys, San Diego). Results were analyzed using the Insight2005 Homology Module (Accelrys, San Diego).

2. In Vitro Antiplasmodial Activity Studies. D10 and W2 Strains. $P$. falciparum cultures were carried out according to Trager and Jensen's, with slight modifications. ${ }^{38}$ The CQ-S, strain D10, and the CQ-R, strain W2, were maintained at 5\% hematocrit (human type A-positive red blood cells) in RPMI 1640 (EuroClone, Celbio; $\mathrm{NaHCO}_{3} 24 \mathrm{mM}$ ) medium with the addition of $10 \%$ heat inactivated A-positive human plasma, $20 \mathrm{mM}$ Hepes, $2 \mathrm{mM}$ glutamine. All the cultures were maintained at $37{ }^{\circ} \mathrm{C}$ in a standard gas mixture consisting of $1 \% \mathrm{O}_{2}, 5 \% \mathrm{CO}_{2}, 94 \% \mathrm{~N}_{2}$. Compounds were dissolved in either water or DMSO and then diluted with medium to achieve the required concentrations (final DMSO concentration $<1 \%$, which is nontoxic to the parasite). Drugs were placed in 96-well, flat-bottom microplates (COSTAR) and serial dilutions were made. Asynchronous cultures with parasitaemia of $1-1.5 \%$ and $1 \%$ final hematocrit were aliquoted into the plates and incubated for $72 \mathrm{~h}$ at $37{ }^{\circ} \mathrm{C}$. Parasite growth was determined spectrophotometrically
(OD650) by measuring the activity of the parasite lactate dehydrogenase ( $\mathrm{pLDH})$, according to a modified version of the method of Makler in control and drug-treated cultures. ${ }^{39}$ The antimalarial activity is expressed as $50 \%$ inhibitory concentrations ( $\left.\mathrm{IC}_{50}\right)$; each $\mathrm{IC}_{50}$ value is the mean and standard deviation of at least three separate experiments performed in duplicate.

3D7 and K1 Strains. All samples were tested in triplicate against the 3D7 and K1 strains. The cultures were maintained in continuous $\log$ phase growth in a RPMI1640 medium supplemented with 5\% wash human A+ erythrocytes, $25 \mathrm{mM}$ HEPES, $32 \mathrm{nM} \mathrm{NaHCO}$, and Albu-MAXII (lipid-rich bovine serum albumin). All cultures and assays were conducted at $37^{\circ} \mathrm{C}$ under an atmosphere of $5 \%$ $\mathrm{CO}_{2}, 5 \% \mathrm{O}_{2}$, and $90 \% \mathrm{~N}_{2}$. Stock compound solutions were prepared in $100 \%$ DMSO at $5 \mathrm{mg} / \mathrm{mL}$. The compounds were further diluted using a complete RPMI1640 medium supplemented with cold hypoxanthine and AlbuMAXII. Assays were preformed on sterile 96-well microtiter plates, with each plate containing $100 \mu \mathrm{L}$ of the parasite culture (1\% parasitaemia, $2.5 \%$ hemacrit). After $24 \mathrm{~h}$ of incubation at $37^{\circ} \mathrm{C}, 3.7 \mathrm{~Bq}$ of $\left[{ }^{3} \mathrm{H}\right]$ hypoxanthine was added to each well. Cultures were incubated for a further $24 \mathrm{~h}$ before they were harvested onto glass-fiber filter mats, and the radioactivity was counted using a Wallac Microbeta 1450 scintillation counter. ${ }^{40}$

3. BHIA Assay. A total of $50 \mu \mathrm{L}$ of an $8 \mathrm{mM}$ solution of hemin dissolved in DMSO was distributed in 96-well U-bottom microplates ( $0.4 \mu \mathrm{mol} /$ well; Costar 3799$)$; $50 \mu \mathrm{L}$ of different compounds in water, in doses ranging from 1 to $8 \mathrm{~mol}$ equiv to hemin, was added to triplicate test wells. In control wells, $50 \mu \mathrm{L}$ of water was added. Water-insoluble compounds were solubilized in $25 \mu \mathrm{L}$ of DMSO and then added to hemin prepared at $16 \mathrm{mM}$ and distributed into the wells in $25 \mu \mathrm{L}$ aliquots. The final concentration of DMSO/ well was kept constant at $25 \%$. $\beta$-Hematin formation was initiated by the addition of $100 \mu \mathrm{L}$ of $8 \mathrm{M}$ acetate buffer ( $\mathrm{pH}$ 5). Plates were incubated at $37{ }^{\circ} \mathrm{C}$ for $18 \mathrm{~h}$ to allow for complete reaction and then centrifuged at $3300 \mathrm{~g}$ for $15 \mathrm{~min}$. The soluble fraction of unprecipitated material was collected (fraction I). The remaining pellet was resuspended with $200 \mu \mathrm{L}$ of DMSO to remove unreacted hematin. Plates were then centrifuged again at $3300 \mathrm{~g}$ for $15 \mathrm{~min}$. The DMSO-soluble fraction (fraction II) was collected and the pellet, consisting of a pure precipitate of $\beta$-hematin, was dissolved in $0.1 \mathrm{M} \mathrm{NaOH}$ (fraction III) for spectroscopic quantitation. A 150 $\mu \mathrm{L}$ aliquot of each fraction (I, II, or III) was transferred onto a new plate and serial 4-fold dilutions in $0.1 \mathrm{M} \mathrm{NaOH}$ were made. The amount of hematin was determined by measuring the absorbance at $405 \mathrm{~nm}$ using a microtiter plate reader (Molecular Devices). A standard curve of hematin dissolved in $0.1 \mathrm{M} \mathrm{NaOH}$ was used to calculate the amount of porphyrin present in each fraction. The drug concentration required to inhibit $\beta$-hematin formation by $50 \%$ $\left(\mathrm{IC}_{50}\right)$ was determined for each compound. ${ }^{25}$

4. Cytotoxicity. Cell Lines. All cell lines were obtained from ATCC. The cells were cultured in RPMI 1640 supplemented with $5 \%$ FCS, $0.1 \mathrm{mM}$ glutamine, $1 \%$ penicillin, and streptomycin. Cells were grown in Nunc clone plastic bottles (TedNunc, Roskilde, Denmark) and split twice weekly at different cell densities according to standard procedure. Perypheral blood mononuclear cells (MNC) were separated from heparinized whole blood obtained from a healthy donor on a Fycoll-Hypaque gradient. MNC thus obtained were washed twice with RPMI 1640 supplemented with $10 \%$ FCS, glutamine, and antibiotics, suspended at 200.000 viable cells $/ \mathrm{mL}$ in medium containing, as mitogen, $5 \mu \mathrm{g} / \mathrm{mL}$ PHA (Sigma) and used in toxicity tests.

Chemicals. MTT (3-(4,5-dimethylthiazol-2-yl)-2,5-diphenyltetrazolium bromide) was purchased from Aldrich. It was dissolved at a concentration of $5 \mathrm{mg} / \mathrm{mL}$ in sterile PBS at room temperature, and the solution was further sterilized by filtration and stored at 4 ${ }^{\circ} \mathrm{C}$ in a dark bottle. SDS was obtained from Sigma. Lysis buffer was prepared as follows: $20 \% \mathrm{w} / \mathrm{v}$ of SDS was dissolved at $37^{\circ} \mathrm{C}$ in a solution of $50 \%$ of each DMF and demineralised water; $\mathrm{pH}$ was adjusted to 4.7 by adding $2.5 \%$ of an $80 \%$ acetic acid and $2.5 \% 1 \mathrm{~N} \mathrm{HCl}$ solution.

Toxicity Experiments. Cells were plated at different concentrations on flat bottom 96 -well microplates ( $0.1 \mathrm{~mL} /$ well). Lympho- 
cytes were plated out at 20000 cells/well. NSO cells (plasmocytoma murine cell line) were plated out at 3000 cells/well, and Daudi cells (human lymphoblastoid cell line) were plated at 300 cells/well. A total of $12 \mathrm{~h}$ after plating, different concentrations of each compound dissolved in DMSO were added to each well. After 48 h, MTT assay was performed to analyze cytotoxicity of the different compounds. All experiments were performed at least two times in triplicate.

KB Cells. KB cells are a cell line derived from a human carcinoma of the nasopharynx, typically used as an assay for antineoplastic agents. KB cells are maintained as monolayers in RPMI $1640+10 \%$ HIFCS. All cultures and assays are conducted at $37{ }^{\circ} \mathrm{C}$ under an atmosphere of $5 \% \mathrm{CO}_{2} / 95 \%$ air mixture. Drug toxicity assays: stock drug solutions were prepared in $100 \%$ DMSO (at $20 \mathrm{mg} / \mathrm{mL}$, and ballmilled or sonicated if necessary). The stocks are kept at $4{ }^{\circ} \mathrm{C}$. For the assays, the compound is further diluted to the appropriate concentration using complete medium. KB cells are harvested, counted, and washed in serum-free medium (2000 $\mathrm{rpm}, 10 \mathrm{~min}, 4^{\circ} \mathrm{C}$ ) and resuspended in fresh medium (RPMI 1640 $+10 \%$ HIFC) at a concentration of $4 \times 10^{4} / \mathrm{mL}$. A total of 100 $\mu \mathrm{L}$ is added to wells on a 96 -well plate $\left(4 \times 10^{3} /\right.$ well). The plate is incubated overnight at $37{ }^{\circ} \mathrm{C}, 5 \% \mathrm{CO}_{2}$ /air mix, to allow the cells to adhere. Test compounds are prepared in $100 \%$ DMSO $20 \mathrm{mg} /$ $\mathrm{mL}$ and diluted down to a starting concentration of $600 \mu \mathrm{g} / \mathrm{mL}$ ( $2 \times$ top concentration) with RPMI $+10 \%$ HIFCS. Control wells have no drug. A 10-fold serial dilution is performed across the plate, $300,30,3$, and so on. Podophyllotoxin is the control drug. The plate is incubated for $72 \mathrm{~h}$ at $37{ }^{\circ} \mathrm{C}, 5 \% \mathrm{CO}_{2} /$ air. Each well is assessed by microscope observation. A $20 \mu \mathrm{L}$ aliquot of Alamar Blue is then added to each well. Plates are incubated for a further 2-4 h before reading (Gemini), EX/EM 530/580, cutoff $550 \mathrm{~nm}$. $\mathrm{IC}_{50}\left(\mathrm{IC}_{90}\right)$ values are calculated using sigmoidal regression analysis (MS $x l$ fit).

MTT/Formazan Extraction Procedure. A total of $20 \mu \mathrm{L}$ of the $5 \mathrm{mg} / \mathrm{mL}$ stock solution of MTT was added to each well; after $2 \mathrm{~h}$ of incubation at $37^{\circ} \mathrm{C}, 100 \mu \mathrm{L}$ of the extraction buffer was added. After an overnight incubation at $37{ }^{\circ} \mathrm{C}$, the optical densities at $570 \mathrm{~nm}$ were measured using a Titer-Tech 96-well multiscanner, employing the extraction buffer as the blank.

5. In Vivo Antiplasmodial Activity Studies. Briefly, blood is taken from donor mice and diluted to a parasitaemia of $1 \%$ (equivalent to $1 \times 10^{7}$ infected erythrocytes $/ \mathrm{mL}$ ). An inoculum of $0.2 \mathrm{~mL}$ is administered to each mouse by the intravenous route. At 2-4 h, post-inoculation dosing commences. Experimental compounds were prepared in $10 \%$ Tween-80/EtOH and sterile PBS. Insoluble formulations were ball-milled and placed into a sonicating waterbath, unheated, for 20-30 min. Compounds were administered in a $0.2 \mathrm{~mL}$ bolus every day for 4 days. The control drug, CQ was administered p.o. every day for 4 days at $10 \mathrm{mg} / \mathrm{kg}$, giving $>90 \%$ parasite clearance on day 4 . On day five post-infection, blood smears of all animals ( 2 slides/mouse) were prepared, fixed with methanol, and stained with $10 \%$ Giemsa stain. Percentage parasitaemia was determined microscopically. Results are reported as \% infected erythrocytes and compared to the CQ control group and the untreated control group.

Acknowledgment. Authors thank Sigma-Tau, Industrie Farmaceutiche Riunite (Campiani et Al. EP06005307.1) for financial support. Marco Persico, Italian Malaria Network, was funded by Compagnia di San Paolo, Torino, Italy. This investigation received financial support from the UNICEF/ UNDP/World Bank/WHO Special Programme for Research and Training in Tropical Diseases (TDR).

Supporting Information Available: Antifungal activity for compounds $\mathbf{4 e , n}, \mathbf{2}$, and $\mathbf{1}$ (Table 1), the corresponding experimental details, and elemental analyses for compounds $3 \mathbf{a}-\mathbf{g}$ and $\mathbf{4 a}-\mathbf{p}$ (Table 2). This material is available free of charge via the Internet at http://pubs.acs.org.

\section{References}

(1) Hay, S. I.; Guerra, C. A.; Tatem, A. J.; Noor, A. M.; Snow, R. W. The global distribution and population at risk of malaria: past, present, and future. Lancet Infect. Dis. 2004, 4, 327-336.

(2) (a) Beckera, K.; Tilley, L.; Vennerstrom, J. L.; Roberts, D.; Rogerson, S.; Ginsburg, H. Oxidative stress in malaria parasite-infected erythrocytes: host-parasite interactions. Int. J. Parasitol. 2004, 34, 163189. (b) Müller, S. Redox and antioxidant systems of the malaria parasite Plasmodium falciparum. Mol. Microbiol. 2004, 53, 12911305.

(3) (a) Fitch, C. D. Ferriprotoporphyrin IX, phospholipids, and the antimalarial actions of quinoline drugs. Life Sci. 2004, 74, 1957-1972. (b) Homewood, C. A.; Moore, G. A.; Warhurst, D. C.; Atkinson, E. M. Purification and some properties of malarial pigment. Annals Trop. Med. Parasitol. 1975, 69, 283-287. (c) Slater, A. F. G.; Swiggard, W. J.; Orton, B. R.; Flitter, W. D.; Goldberg, D. E.; Cerami, A.; Henderson, G. B. An iron-carboxylate bond links the heme units of malaria pigment. Proc. Natl. Acad. Sci. U.S.A. 1991, 88, 325-329. (d) Pagola, S.; Stephens, P. W.; Bohle, S. D.; D. Kosar, A. D.; Madsen, S. K. The structure of malaria pigment $\beta$-haematin. Nature 2000, 404, 307-310. (e) Ginsburg, H.; Famin, O.; Zhang, J.; Krugliak, M. Inhibition of glutathione-dependent degradation of heme by chloroquine and amodiaquine as a possible basis for their antimalarial mode of action. Biochem. Pharmacol. 1998, 56, 1305-1313. (f) Famin, O.; Krugliak, M.; Ginsburg, H. Kinetics of inhibition of glutathionemediated degradation of ferriprotoporphyrin IX by antimalarial drugs. Biochem. Pharmacol. 1999, 58, 59-68.

(4) (a) Towie, N. Malaria breakthrough raises spectre of drug resistance. Nature 2006, 440, 452-453. (b) Afonso, A.; Hunt, P; Cheesman, S.; C.; Alves, A.; Cunha, C. V.; do Rosario, V.; Cravo, P. Malaria parasites can develop stable resistance to artemisinin but lack mutations in candidate genes atp6 (encoding the sarcoplasmic and endoplasmic reticulum $\mathrm{Ca}^{2+}$ ATPase), tctp, mdr1, and cg10. Antimicrob. Agents Chemother. 2006, 50, 480-489.

(5) (a) Gemma, S.; Kukreja, G.; Campiani, G.; Butini, S.; Bernetti, M.; Joshi, B. P.; Savini, L.; Basilico, N.; Taramelli, D.; Yardley, V.; Bertamino, A.; Novellino, E.; Persico, M.; Catalanotti, B.; Fattorusso, C. Development of piperazine-tethered heterodimers as potent antimalarials against chloroquine-resistant P. falciparum strains. Synthesis and molecular modelling. Bioorg. Med. Chem. Lett. 2007, 17, 35353539. (b) Gemma, S.; Kukreja, G.; Fattorusso, C.; Persico, M.; Romano, M. P.; Altarelli, M.; Savini, L.; Campiani, G.; Fattorusso, E.; Basilico, N.; Taramelli, D.; Yardley, V.; Butini, S. Synthesis of $N 1$-arylidene-N2-quinolyl- and N2-acrydinylhydrazones as potent antimalarial agents active against CQ-resistant $P$. falciparum strains. Bioorg. Med. Chem. Lett. 2006, 16, 5384-5388. (c) Fattorusso, C.; Campiani, G.; Catalanotti, B.; Persico, M.; Basilico, N.; Parapini, S.; Taramelli, D.; Campagnuolo, C.; Fattorusso, E.; Romano, A.; Taglialatela-Scafati, O. Endoperoxide derivatives from marine organisms: 1,2-dioxanes of the plakortin family as novel antimalarial agents. J. Med. Chem. 2006, 49, 7088-7094.

(6) Gemma, S.; Campiani, G.; Butini, S.; Kukreja, G.; Joshi, B. P.; Persico, M.; Catalanotti, B.; Novellino, E.; Fattorusso, E.; Nacci, V.; Savini, L.; Taramelli, D.; Basilico, N.; Morace, G.; Yardley, V.; Fattorusso, C. Design and synthesis of potent antimalarial agents based on clotrimazole scaffold: Exploring an innovative pharmacophore. J. Med. Chem. 2007, 50, 595-598.

(7) Tiffert, T.; Ginsburg, H.; Krugliak, M.; Elford, B. C.; Lew, V. L. Potent antimalarial activity of clotrimazole in in vitro cultures of Plasmodium falciparum. Proc. Natl. Acad. Sci. U.S.A. 2000, 97, 331-336.

(8) Saliba, K. J.; Kirk, K. Clotrimazole inhibits the growth of Plasmodium falciparum in vitro. Trans. R. Soc. Trop. Med. Hyg. 1998, 92, 666667.

(9) Trivedi, V.; Chand, P.; Srivastava, K.; Puri, S. K.; Maulik, P. R.; Bandyopadhyay, U. Clotrimazole inhibits hemoperoxidase of Plasmodium falciparum and induces oxidative stress. J. Biol. Chem. 2005, 280, 41129-41136.

(10) Chong, C. R.; Sullivan, D. J., Jr. Inhibition of heme crystal growth by antimalarials and other compounds: Implications for drug discovery. Biochem. Pharmacol. 2003, 66, 2201-2212.

(11) Huy, N. T.; Kamei, K.; Yamamoto, T.; Kondo, Y.; Kanaori, K.; Takano, R.; Tajima, K.; Hara, S. Clotrimazole binds to heme and enhances heme-dependent hemolysis. J. Biol. Chem. 2002, 277, 41524158.

(12) Eaton, D. R.; Wilson, K. M. Reaction of imidazole and hydroquinone with oxymyoglobin. J. Inorg. Biochem. 1979, 10, 195-203.

(13) Eaton, D. R.; Wilkins, R. G. Reduction by dithionite ion of adducts of metmyoglobin with imidazole, pyridine, and derivatives. J. Biol. Chem. 1978, 253, 908-915.

(14) Hicks, R. G. What's new in stable radical chemistry? Org. Biomol. Chem. 2007, 5, 1321-1338. 
(15) Short, J. H. Formation of Grignard reagents from 3-bromo- $N, N$ dimethylbenzylamine and 4-bromo- $N, N$-diethylbenzylamine and their reactions with benzaldehyde. J. Chem. Soc. C 1966, 313-315.

(16) Thorsett, E. D.; Stermitz, F. R. Alkylation of haloquinolines by Grignard reagents with nickel-phosphine complex catalysts. J. Heterocycl. Chem. 1973, 10, 243-244.

(17) Slama, J. T.; Hancock, J. L.; Rho, T.; Sambucetti, L.; Bachmann, K. A. Influence of some novel N-substituted azoles and pyridines on rat hepatic CYP3A activity. Biochem. Pharmacol. 1998, 55, 1881-1892.

(18) Heindel, N. D.; Fine, S. A. Acid-catalyzed alcoholysis of 4,7dichloroquinoline. J. Heterocycl. Chem. 1969, 6, 961.

(19) Yamanaka, H.; Ohba, S. Reaction of methoxy- $N$-heteroarmatics with phenylacetonitrile under basic conditions. Heterocycles 1990, 31, 895909.

(20) Da Silva, G.; Moore, E. E.; Bozzelli, J. W. Quantum chemical study of the structure and thermochemistry of the five-membered nitrogencontaining hetrocycles and their anions and radicals. J. Phys. Chem. A 2006, 110, 13979-13988.

(21) Inbaraj, J.; Bilski, P.; Chignell, C. F. Photophysical and photochemical studies of 2-phenylbenzimidazole and UVB sunscreen 2-phenylbenzimidazole-5-sulfonic acid. Photochem. Photobiol. 2002, 75, 107-116.

(22) Mabeza, G. F.; Loyevsky, M.; Gordeuk, V. R.; Weiss, G. Iron chelation therapy for malaria: A review. Pharmacol. Ther. 1999, 81, 53-75.

(23) (a) O’Neill, P. M.; Ward, S. A.; Berry, N. G.; Jeyadevan, J. P.; Biagini, G. A.; Asadollaly, E.; Park, B. K.; Bray, P. G. A medicinal chemistry perspective on 4-aminoquinoline antimalarial drugs. Curr. Top. Med. Chem. 2006, 6, 479-507. (b) Sparatore, A.; Basilico, N.; Parapini, S.; Romeo, S.; Novelli, F.; Sparatore, F.; Taramelli, D. 4-Aminoquinoline quinolizidinyl- and quinolizidinylalkyl- derivatives with antimalarial activity. Bioorg. Med. Chem. 2005, 13, 5338-5345.

(24) Ursos, L. M. B.; Roepe, P. D. Chloroquine resistance in the malarial parasite, Plasmodium falciparum. Med. Res. Rev. 2002, 22, 465-491.

(25) Parapini, S.; Basilico, N.; Pasini, E.; Egan, T. J.; Olliaro, P.; Taramelli, D.; Monti, D. Standardization of the physicochemical parameters to assess in vitro the $\beta$-hematin inhibitory activity of antimalarial drugs. Exp. Parasitol. 2000, 96, 249-256.

(26) Holtje, H. D.; Fattorusso, C. Construction of a model of the Candida albicans lanosterol 14-alpha-demethylase active site using the homology modelling technique. Pharm. Acta Helv. 1998, 72, 271-277.

(27) Winn, P. J.; Ludemann, S. K.; Gauges, R.; Lounnas, V.; Wade, R. C. Comparison of the dynamics of substrate access channels in three cytochrome P450s reveals different opening mechanisms and a novel functional role for a buried arginine. Proc. Natl. Acad. Sci. U.S.A. 2002, 99, 5361-5366.
(28) (a) D'Atri, S.; Tentori, L.; Fuggetta, M. P.; Marini, S.; Bonmassar, E. A miniaturized cell-mediated cytotoxicity assay with human effector mononuclear cells. Int. J. Tissue React. 1986, 8, 383-390. (b) Scatena, R.; Marini, S.; Tavazzi, B.; Lazzarino, G.; Giardina, B. Sterol metabolism and lymphocyte function: measure of relative LDL receptor number by peripheral blood lymphocytes activation. Clin. Chem. Enzymol. Commun. 1990, 3, 73-79.

(29) Peters, W.; Robinson, B. L. In Handbook of Animal Models of Infection; Zak., O., Sande, M., Eds.; Academic: London, 1999; pp 757-773.

(30) Short, J. H. Formation of Grignard reagents from 3-bromo- $N, N$ dimethyl-benzylamine and 4-bromo- $N, N$-diethylbenzylamine and their reactions with benzaldehyde. J. Chem. Soc. C 1966, 3, 313-315.

(31) Bender, D. R.; Coffen, D. L. Synthetic quinine analogs. V. Quinolinemethanols related to desvinylquinine. J. Heterocycl. Chem. 1971, 8, 937-942.

(32) Maple, J. R.; Hwang, M. J.; Stockfisch, T. P.; Dinur, U; Waldman, M.; Ewig, C. S.; Hagler, A. T. Derivation of class II force fields. I. Methodology and quantum force field for the alkyl functional group and alkane molecules. J. Comput. Chem. 1994, 15, 162-182.

(33) Dewar, M. J. S.; Thiel, W. Ground states of molecules. 38. The MNDO method. Approximations and parameters. J. Am. Chem. Soc. 1977, 99, 4899-4907.

(34) Fletcher, R. Unconstrained Optimization. In Pratical Methods of Optimization; John Wiley \& Sons: New York, 1980; Vol. 1.

(35) Stewart, J. J. P. MOPAC: a semiempirical molecular orbital program. J. Comput.-Aided Mol. Des. 1990, 4, 1-105.

(36) Senderowitz, H.; Guarnieri, F.; Still, W. C. A smart Monte Carlo technique for free energy simulations of multiconformational molecules. Direct calculations of the conformational populations of organic molecules. J. Am. Chem. Soc. 1995, 117, 8211-8219.

(37) Ding, H. Q.; Karasawa, N.; Goddard, W. A., III. Atomic level simulations on a million particles: The cell multipole method for Coulomb and London non-bond interactions. J. Chem. Phys. 1992, 97, 4309-4315.

(38) Trager, W.; Jensen, J. B. Human malaria parasites in continuous culture. Science 1976, 193, 673-675.

(39) Makler, M.; Hinrichs, D. Measurement of the lactate dehydrogenase activity of Plasmodium falciparum as an assessment of parasitemia. Am. J. Trop. Med. Hyg. 1993, 48, 205-210.

(40) Desjardins, R. E.; Canfiled, C. J.; Haynes, J. D.; Chulay, J. D. Quanititative assessment of antimalarial activity in vitro by a semiautomated microdilution technique. Antimicrob. Agents Chemother. 1979, 16, 710-718.

JM701247K 